\title{
Review \\ C Proteins: Controllers of Orderly Paramyxovirus Replication and of the Innate Immune Response
}

\author{
Oliver Siering ${ }^{1}$, Roberto Cattaneo ${ }^{2, *(1)}$ and Christian K. Pfaller ${ }^{1, *(1)}$ \\ 1 Division of Veterinary Medicine, Paul-Ehrlich-Institute, 63225 Langen, Germany; Oliver.Siering@pei.de \\ 2 Department of Molecular Medicine, Mayo Clinic, Rochester, MN 55906, USA \\ * Correspondence: Cattaneo.Roberto@mayo.edu (R.C.); Christian.Pfaller@pei.de (C.K.P.)
}

check for updates

Citation: Siering, O.; Cattaneo, R.; Pfaller, C.K. C Proteins: Controllers of Orderly Paramyxovirus Replication and of the Innate Immune Response. Viruses 2022, 14, 137. https:/ / doi.org/10.3390/v14010137 Academic Editors: Rob W Ruigrok and Martin Blackledge

Received: 9 December 2021

Accepted: 9 January 2022

Published: 12 January 2022

Publisher's Note: MDPI stays neutral with regard to jurisdictional claims in published maps and institutional affiliations.

Copyright: () 2022 by the authors Licensee MDPI, Basel, Switzerland. This article is an open access article distributed under the terms and conditions of the Creative Commons Attribution (CC BY) license (https:// creativecommons.org/licenses/by/ $4.0 /)$.

\begin{abstract}
Particles of many paramyxoviruses include small amounts of proteins with a molecular weight of about $20 \mathrm{kDa}$. These proteins, termed " $\mathrm{C}$ ", are basic, have low amino acid homology and some secondary structure conservation. $C$ proteins are encoded in alternative reading frames of the phosphoprotein gene. Some viruses express nested sets of $C$ proteins that exert their functions in different locations: In the nucleus, they interfere with cellular transcription factors that elicit innate immune responses; in the cytoplasm, they associate with viral ribonucleocapsids and control polymerase processivity and orderly replication, thereby minimizing the activation of innate immunity. In addition, certain $C$ proteins can directly bind to, and interfere with the function of, several cytoplasmic proteins required for interferon induction, interferon signaling and inflammation. Some $\mathrm{C}$ proteins are also required for efficient virus particle assembly and budding. C-deficient viruses can be grown in certain transformed cell lines but are not pathogenic in natural hosts. $C$ proteins affect the same host functions as other phosphoprotein gene-encoded proteins named $\mathrm{V}$ but use different strategies for this purpose. Multiple independent systems to counteract host defenses may ensure efficient immune evasion and facilitate virus adaptation to new hosts and tissue environments.
\end{abstract}

Keywords: Paramyxoviridae; Orthoparamyxovirinae; replication; nucleocapsid; processivity; defectiveinterfering RNA; immune evasion; inflammasome; budding; ESCRT

\section{Introduction}

About 50 years ago, when the proteins from purified particles of different paramyxoviruses were first analyzed, several polypeptides were identified and their biological roles tentatively attributed [1-5]. Three proteins (nucleocapsid, polymerase and phosphoprotein) are now known to constitute the replicative complex, and three others (attachment, fusion and matrix proteins) constitute the membrane fusion apparatus [6]. Another particleassociated protein with a molecular weight (MW) of about 42.000, labeled A, turned out to be cellular actin [7].

When the synthesis of virus-specific proteins was analyzed in infected cells, two proteins not found in particles, and thus deemed nonstructural, were identified [7]. These proteins had MWs of about 36,000 and 20,000, respectively, and were labeled with the letters B and C. Alternatively, the MW 36,000 protein was labeled with the Roman numeral $\mathrm{V}$ (five) that was sometimes pronounced as the letter $\mathrm{V}$.

When these two proteins, currently named $V$ and $C$, were shown to be minor virus particle components, the nonstructural nomenclature was dropped. When reverse genetics showed that $\mathrm{V}$ and $\mathrm{C}$ are not essential for virus replication, they were reclassified as "accessory" [8-11]. However, even this classification is misleading, because both $\mathrm{V}$ and $C$ are required for the productive infection of natural hosts [12-15]. We review here the multiple functions of the paramyxovirus $C$ proteins in the control of virus replication and of the host innate immune response and propose that C should stand for "control". 


\section{C Proteins Are Expressed from Alternative Open Reading Frames in the P/V/C Genes}

Paramyxoviruses (Figure 1A) have non-segmented RNA genomes of negative polarity that are 15-20 kilobases in length. Most mRNAs transcribed from these templates code for a single protein product, but early analyses of Sendai virus $(\mathrm{SeV})$ phosphoprotein $(\mathrm{P})$ mRNA suggested it might encode the $C$ protein in addition to the $P$ protein [16]. Indeed, the SeV P mRNA nucleotide sequence revealed two overlapping reading frames. The first encodes the 588-amino acid P protein; the second starts at an AUG located 10 nucleotides downstream of the P AUG and codes for the 204-amino acid C protein [17] (Figure 1B, top center).

A

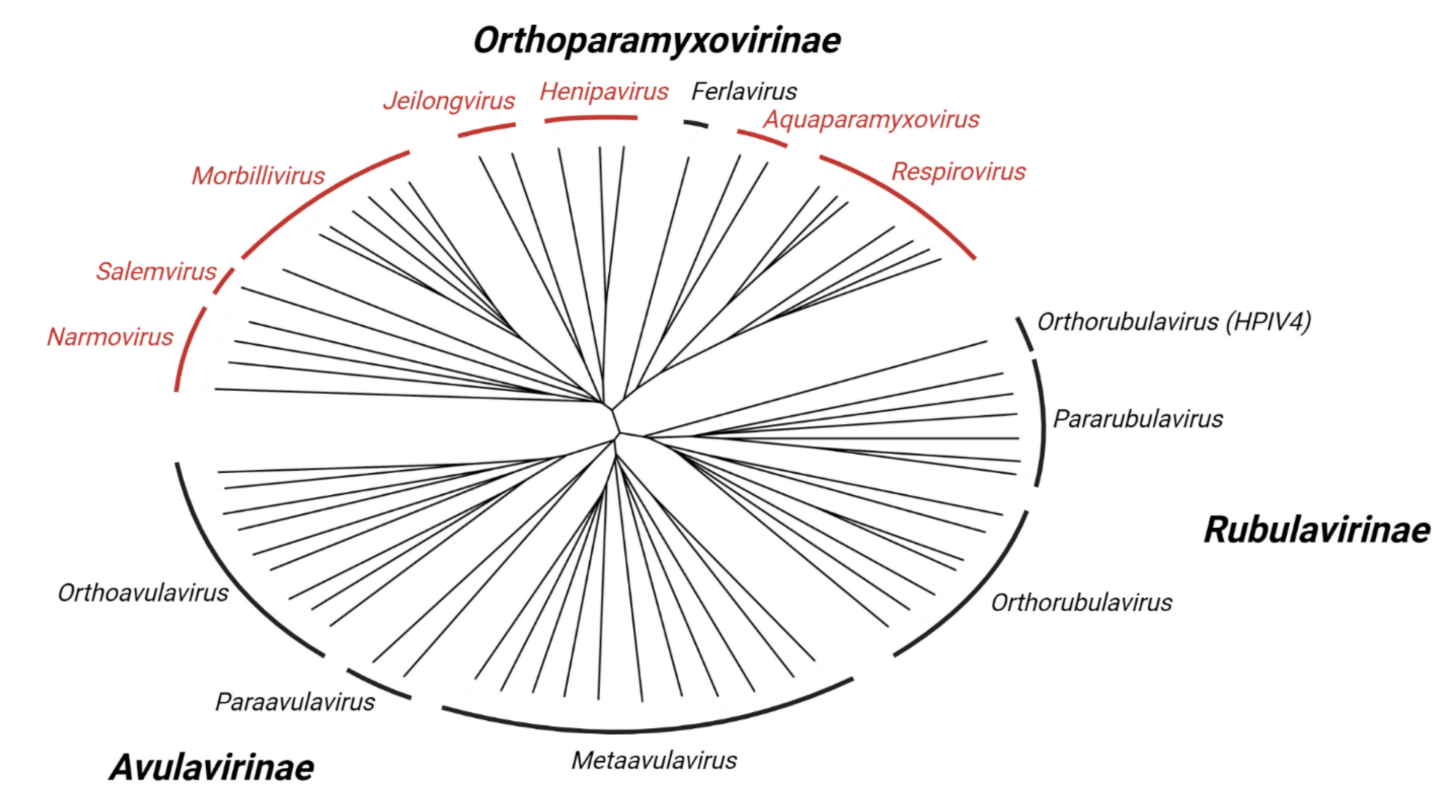

B
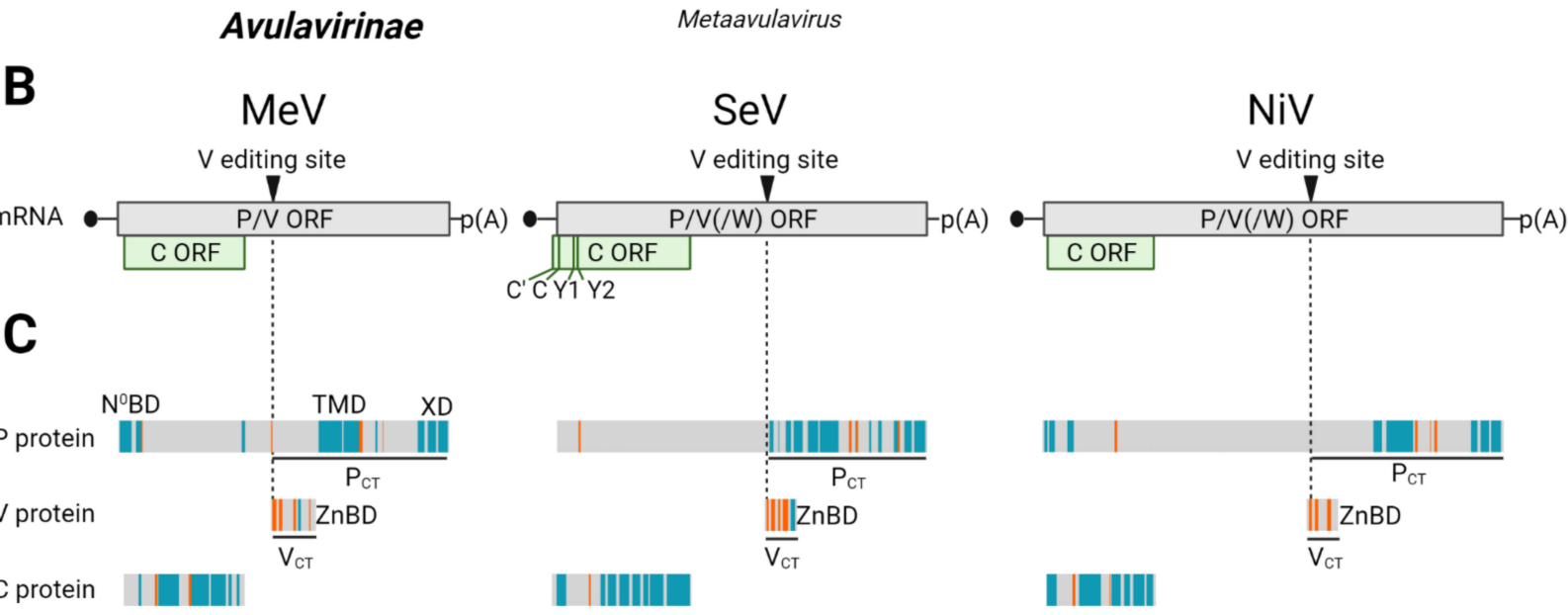

Figure 1. C protein expression among viruses of the Paramyxoviridae family. (A) Phylogenetic tree indicating subfamilies and genera. The tree is based on full genome alignment of available reference genomes in GenBank using CLUSTALW [18] and was generated with iTOL [19]. Viruses of genera in red express $C$ proteins. (B) Organization of the overlapping open reading frames in the mRNAs derived from the $\mathrm{P} / \mathrm{V} / \mathrm{C}$ genes of $\mathrm{MeV}$ (left), $\mathrm{SeV}$ (center) and $\mathrm{NiV}$ (right). SeV expresses four $\mathrm{C}$ proteins from alternative start codons named $C^{\prime}, C, Y 1$ and $Y 2$. (C) Secondary structure predictions for $\mathrm{P}$ and $\mathrm{C}$ proteins, as well as the $\mathrm{V}$ protein-specific carboxy-terminus $\left(\mathrm{V}_{\mathrm{CT}}\right)$. Alpha-helices are depicted in blue, beta strands in orange and unstructured (coiled) regions are shown in grey. Underlined regions in $\mathrm{P}$ and $\mathrm{V}$ proteins correspond to their unique carboxy-termini $\left(\mathrm{P}_{\mathrm{CT}}\right.$ and $\left.\mathrm{V}_{\mathrm{CT}}\right) . \mathrm{N}^{0} \mathrm{BD}$ : binding domain interacting with free nucleoprotein; TMD: tetramerization domain of $\mathrm{P} ; \mathrm{XD}$ : domain of $\mathrm{P}$ interacting with $\mathrm{N}_{\text {tail }}$ of the nucleocapsid; ZnBD: Zn-binding domain of $\mathrm{V}$ protein that interacts with several host innate immunity factors. Figure generated with BioRender.com. 
Successive analyses of the measles virus $(\mathrm{MeV}) \mathrm{P}$ gene revealed a similar gene organization: the MeV C AUG is located 22 nucleotides downstream of the P AUG [20] (Figure 1B, top left). Initially, no sequence homology was detected between the $\mathrm{SeV}$ and $\mathrm{MeV} C$ proteins. A third type of $C$ proteins was discovered when the $P$ gene of the newly emerged Nipah virus (NiV) was sequenced [21] (Figure 1B, top right). The NiV C AUG is located 23 nucleotides downstream of the P AUG, putting it in the " +2 " reading frame, while both the $\mathrm{SeV}$ and $\mathrm{MeV} \mathrm{C}$ reading frames are " +1 ", as compared to the respective $\mathrm{P}$ reading frames.

$\mathrm{C}$ proteins, or candidate $\mathrm{C}$ protein reading frames, are common but not ubiquitous in paramyxoviruses; they have been characterized in 26 of the 63 genomic reference sequences currently available in GenBank (Figure 1A; paramyxovirus genera expressing C proteins are shown in red and Table 1). On the other hand, almost every paramyxovirus $P$ gene encodes a third product, the $\mathrm{V}$ protein. $\mathrm{V}$ proteins consist of the amino-terminal half of $\mathrm{P}$ fused to a carboxyl-terminal domain highly conserved in the Paramyxoviridae that includes seven invariant cysteines [22,23] (Figure 1C, center). In different paramyxoviruses, $\mathrm{V}$ proteins are either produced by a frame shift introduced by RNA editing or from unedited RNA, while the $\mathrm{P}$ expression depends on editing [6]. Even if the $\mathrm{V}$ and $\mathrm{C}$ proteins have completely different sequences and structures, they can accomplish similar tasks by operating through different mechanisms [24]. V proteins are particularly important for virus genera that lack $C$ proteins, while genera that express both proteins have the option to counteract host defenses through alternative strategies in different cells and tissues. Our review will focus on the functions of $\mathrm{C}$ proteins. The different functions of $\mathrm{V}$ proteins have been comprehensively reviewed elsewhere [24-28].

Table 1. Overview of $C$ protein-expressing paramyxoviruses.

\begin{tabular}{|c|c|c|c|c|c|c|}
\hline \multirow{2}{*}{ Genus } & \multirow{2}{*}{ Species } & \multirow{2}{*}{ Abbreviation } & \multirow{2}{*}{$\begin{array}{c}\begin{array}{c}\text { Genome } \\
\text { Sequence }\end{array} \\
\text { (GenBank) }\end{array}$} & \multicolumn{2}{|c|}{ C Protein Sequence } & \multirow{2}{*}{ Reference } \\
\hline & & & & (GenBank) & (UniProt/UniParc) & \\
\hline \multirow{2}{*}{$\begin{array}{l}\text { Aquapara- } \\
\text { myxovirus }\end{array}$} & $\begin{array}{c}\text { Oncorhynchus } \\
\text { aquaparamyxovirus }\end{array}$ & PSPV & MH900516.1 & AYN62575.1 & I1TLL1 & [29] \\
\hline & $\begin{array}{c}\text { Salmo } \\
\text { aquaparamyxovirus }\end{array}$ & ASPV & NC_025360.1 & YP_009094145.1 & B2BX73 & {$[30]$} \\
\hline \multirow{3}{*}{ Henipavirus } & Cedar henipavirus & $\mathrm{CeV}$ & NC_025351.1 & YP_009094083.1 & J7H4I1 & {$[31]$} \\
\hline & Hendra henipavirus & $\mathrm{HeV}$ & NC_001906.3 & NP_047109.1 & O55779 & [32] \\
\hline & Nipah henipavirus & $\mathrm{NiV}$ & NC_002728.1 & NP_112024.1 & Q997F1 & [33] \\
\hline \multirow{2}{*}{ Jeilongvirus } & Beilong jeilongvirus & $\mathrm{BeV}$ & NC_007803.1 & YP_512248.1 & Q287X7 & {$[34]$} \\
\hline & Jun jeilongvirus & $\mathrm{J}-\mathrm{V}$ & NC_007454.1 & YP_338079.1 & Q49HN8 & [35] \\
\hline \multirow{7}{*}{ Morbillivirus } & Canine morbillivirus & CDV & NC_001921.1 & NP_047203.1 & P06941 & [36] \\
\hline & Cetacean morbillivirus & CeMV & NC_005283.1 & NP_945026.1 & Q709E7 & [37] \\
\hline & Feline morbillivirus & FeMV & NC_039196.1 & YP_009512960.1 & UPI000259F006 & [38] \\
\hline & Measles morbillivirus & $\mathrm{MeV}$ & NC_001498.1 & NP_056920.1 & Q9YZN9 & [39] \\
\hline & Phocine morbillivirus & PMV & NC_028249.1 & YP_009177600.1 & P35940 & {$[40]$} \\
\hline & $\begin{array}{l}\text { Rinderpest } \\
\text { morbillivirus }\end{array}$ & RPV & NC_006296.2 & YP_087122.1 & P35948 & [41] \\
\hline & $\begin{array}{l}\text { Small ruminant } \\
\text { morbillivirus }\end{array}$ & PPRV & NC_006383.2 & YP_133824.1 & Q5ZER5 & [42] \\
\hline
\end{tabular}


Table 1. Cont.

\begin{tabular}{|c|c|c|c|c|c|c|}
\hline \multirow{2}{*}{ Genus } & \multirow{2}{*}{ Species } & \multirow{2}{*}{ Abbreviation } & \multirow{2}{*}{$\begin{array}{c}\text { Genome } \\
\text { Sequence }\end{array}$} & \multicolumn{2}{|c|}{ C Protein Sequence } & \multirow{2}{*}{ Reference } \\
\hline & & & & (GenBank) & (UniProt/UniParc) & \\
\hline \multirow{4}{*}{ Narmovirus } & Mossman narmovirus & $\mathrm{MoV}$ & NC_005339.1 & NP_958051.1 & Q6WGM3 & [43] \\
\hline & Myodes narmovirus & $\mathrm{BaVV}$ & NC_055167.1 & YP_010085011.1 & $\mathrm{N} / \mathrm{A}$ & [44] \\
\hline & Nariva narmovirus & NarV & NC_017937.1 & YP_006347585.1 & B8XH61 & [45] \\
\hline & Tupaia narmovirus & TPMV & NC_002199.1 & NP_054693.1 & Q9WS38 & [46] \\
\hline \multirow{7}{*}{ Respirovirus } & Bovine respirovirus 3 & BPIV3 & NC_002161.1 & $\mathrm{N} / \mathrm{A}$ & $\mathrm{N} / \mathrm{A}$ & [47] \\
\hline & Caprine respirovirus 3 & CPIV3 & NC_028362.1 & $\mathrm{N} / \mathrm{A}$ & $\mathrm{N} / \mathrm{A}$ & [48] \\
\hline & Human respirovirus 1 & HPIV1 & NC_003461.1 & NP_604436.1 & Q8QT30 & [49] \\
\hline & Human respirovirus 3 & HPIV3 & NC_001796.2 & NP_599251.1 & UPI0000161E9C & [50] \\
\hline & Murine respirovirus & $\mathrm{SeV}$ & NC_001552.1 & NP_056872.1 & O55527 & [51] \\
\hline & Porcine respirovirus 1 & PPIV1 & NC_025402.1 & YP_009094446.1 & S5LSI4 & [52] \\
\hline & Squirrel respirovirus & GSqRV & LS992584.1 & SYZ47172.1 & A0A383S9W5 & [53] \\
\hline Salemvirus & Salem salemvirus & SalV & NC_025386.1 & YP_009094334.1 & Q9IZB9 & [54] \\
\hline
\end{tabular}

N/A: no sequence accession number available in GenBank or UniProt; C protein ORFs of these viruses were identified in the genome sequence and translated. Prototype species $\mathrm{NiV}, \mathrm{MeV}$ and $\mathrm{SeV}$ in bold face.

\section{All Three Types of C Proteins Include an Intrinsically Disordered Part}

While the primary amino acid conservation of $C$ proteins is very low, it is sufficient to categorize them into three distinct groups [55] (Figure 2, left). Proteins from the Henipavirus, Salemvirus and Jeilongvirus genera form group 1; proteins from the Morbillivirus and Narmovirus genera form group 2 and proteins from the Respirovirus and Aquaparamyxovirus genera form group 3 (Figure 2, top to bottom).

Secondary structure predictions indicate that the carboxy-terminal part of all C proteins is rich in alpha-helixes, whereas little secondary structures are predicted for the amino-terminal part, which appears to be intrinsically disordered (Figure 2, right). The C proteins of groups 1 and 2 show high similarities in their predicted secondary structures, whereas group $3 \mathrm{C}$ proteins are more distant from the other two groups.

Notably, when the $P$ and the $C$ reading frames overlap, only one of them is predicted to fold into alpha-helixes or beta-strands, whereas the other appears to be intrinsically disordered (Figure 1C), a characteristic of dynamic protein structures [60]. Intrinsically disordered segments may be required for the P protein to walk the polymerase down the ribonucleocapsids (RNPs) during replication and transcription and may allow $\mathrm{C}$ to interact with several different cellular partners. 


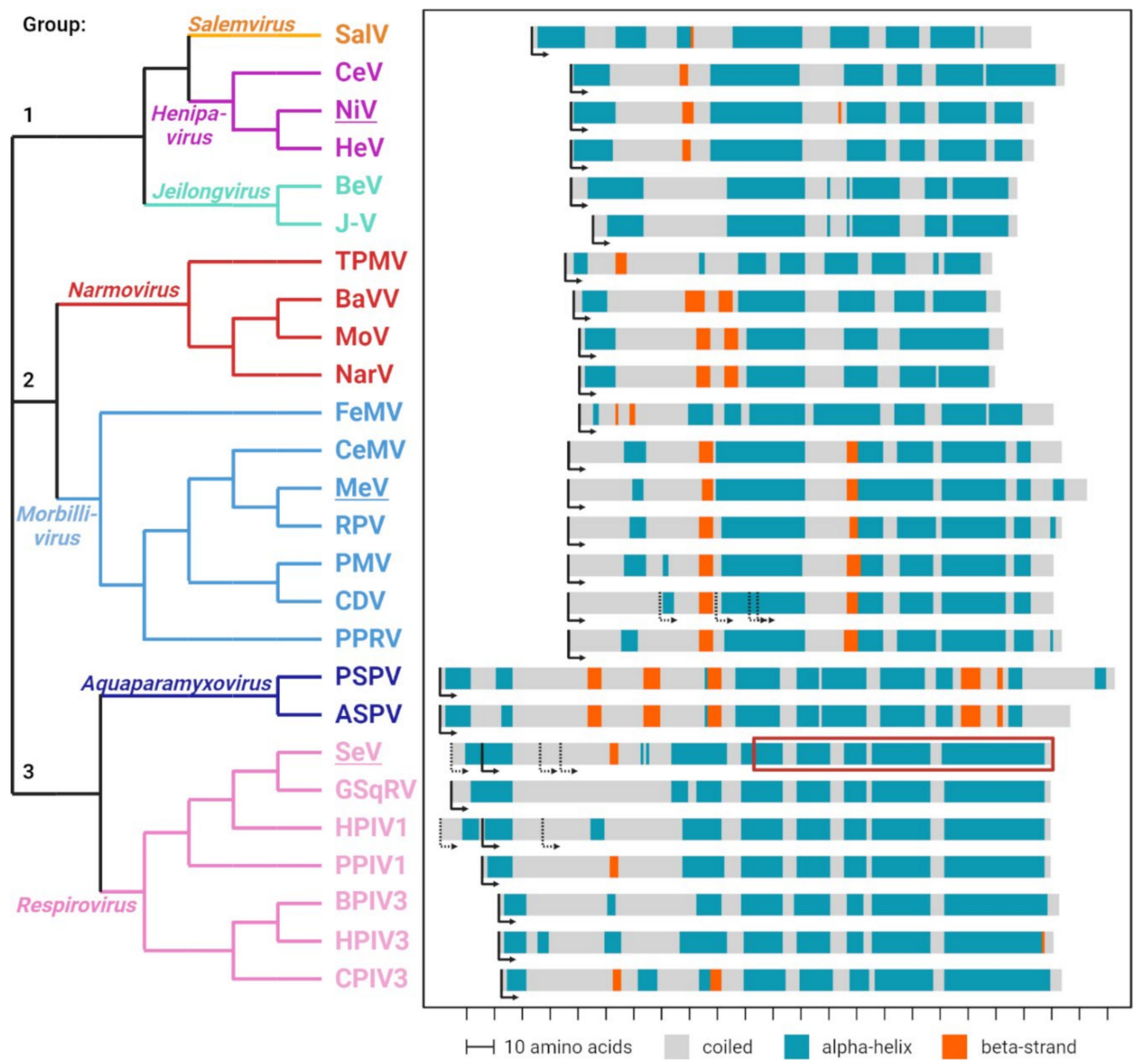

Figure 2. Sequence and structure comparison of paramyxoviral $\mathrm{C}$ proteins. Phylogenetic analysis of the $C$ protein sequences (left). Different genera are highlighted in individual colors. Prototype species underlined. Sequences were aligned using the PROMALS3D tool [56], and a phylogenetic analysis was done via the neighbor-joining clustering method using the EMBL-EBI Simple Phylogeny tool [57]. Predicted secondary structures of the different C proteins (right). Alpha-helices are depicted in blue, beta strands in orange and unstructured (coiled) regions are shown in grey. Translation initiation codons are indicated by arrows. Predictions were performed with the JPred tool [58]. The red box indicates the region in the SeV C protein for which a tertiary structure is available (PDB 3WWT) [59]. Figure generated with BioRender.com.

\section{Functional Insights from the SeV C-STAT1 Complex Structure}

The structures of intrinsically disordered proteins are difficult to determine, but complexes of parts of the SeV C protein (amino acids 98-204) with two different cellular partners have been crystallized. In one complex, the $C$ protein associates with the signal transducer and activator of transcription 1 (STAT1), a transcription factor involved in the interferon (IFN) response (PDB 3WWT) [59]. The second partner is the ALG2-interacting protein $X$ (ALIX), a component of the endosomal sorting complex required for transport (ESCRT) (PDB 6KP3) [61].

Figure 3A provides a lateral view of the SeV C-STAT1 complex, illustrating the compact globular folding of the $\mathrm{C}$ alpha-helical domain (Figure $3 \mathrm{~A}$, gold), which may be similar in other C proteins. Notably, STAT1 and ALIX bind to opposite surfaces of the SeV C protein 
(Figure 3A,B). Several functions of the $C$ proteins have been mapped to the alpha-helical carboxy-terminal half, which is consistent with the suggestion that this intrinsically disordered part either binds different proteins or controls the access of different partners to the alpha-helical part.

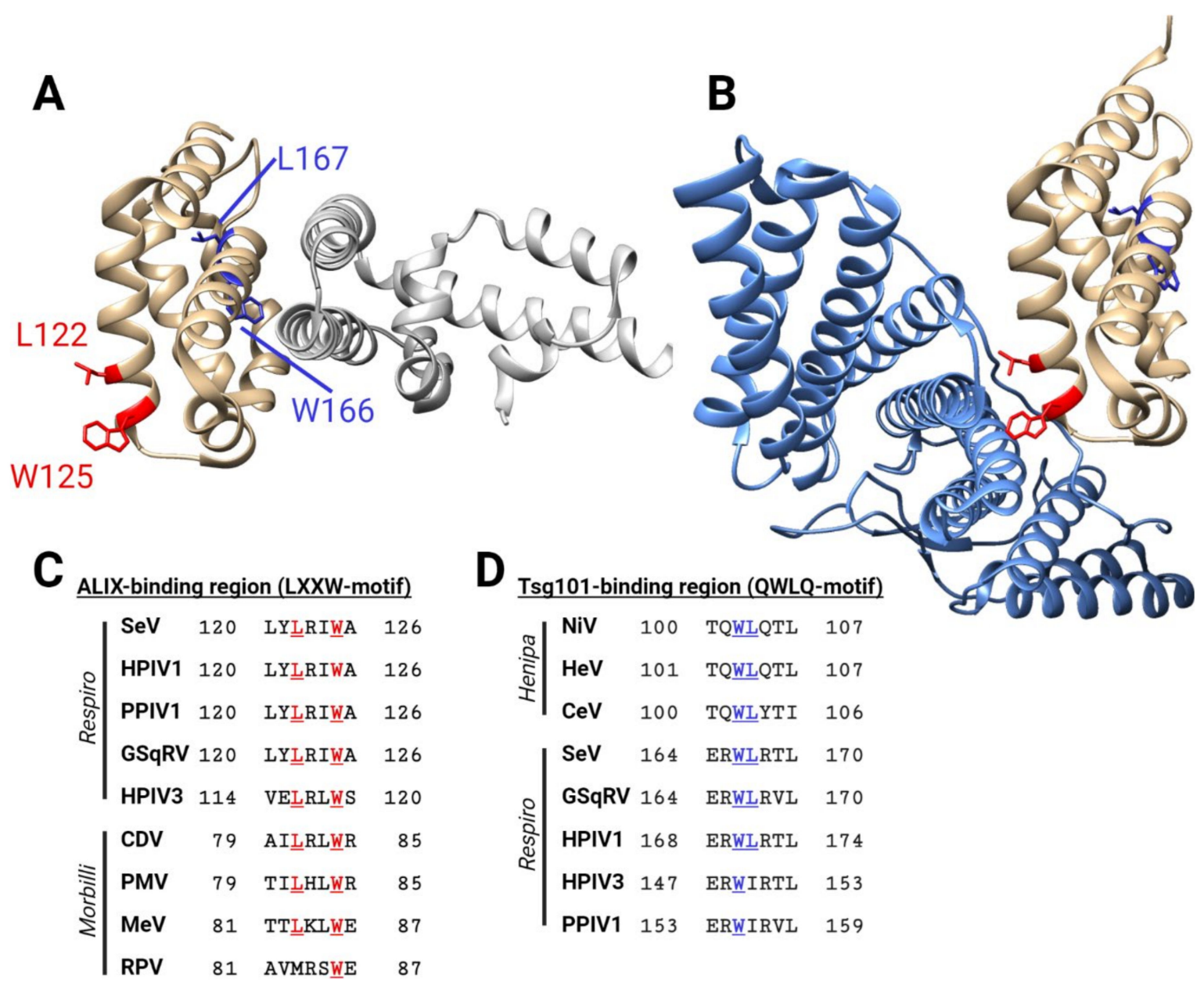

Figure 3. Structural features of the SeV C protein. (A) SeV C protein (amino acid residues 99-204, shown in gold) in a complex with STAT1 (silver) (PDB 3WWT) [59]. Residues important for binding to ALIX (LXXW motif) are shown in red; potential Tsg101-binding residues (QWLQ-motif) are shown in blue. (B) SeV C protein (amino acid residues 99-204, shown in gold) in a complex with the BRO1 domain of ALIX (light blue) (PDB 6KP3) [61]. (C) Conserved ALIX-binding motifs in respiroviruses (top five sequences), and homologous residues in morbilliviruses (bottom four sequences). (D) Conserved Tsg101-binding motifs in henipaviruses (top three sequences), and homologous residues in respiroviruses (bottom 5 sequences). Figure generated with BioRender.com.

Several lines of evidence support this assumption. First, SeV and HPIV1 use several alternative start codons within the intrinsically disordered segment for the translation initiation of elongated $\left(C^{\prime}\right)$ or truncated $(Y 1, Y 2) C$ proteins $[62,63]$; even the smallest so far detected $\mathrm{C}$ protein isoform $\mathrm{Y} 2$ retains the majority of its biological functions [64]. More-over, the morbillivirus CDV also generates $C$ proteins with multiple alternative start codons, but only a recombinant CDV unable to express all $C$ proteins is strongly attenuated in vitro and in vivo [65]. Finally, biochemical studies on artificially truncated $\mathrm{C}$ proteins of SeV, HPIV3 and MeV suggest that their amino terminus is not essential for $\mathrm{C}$ protein functions on regulation of viral replication or innate immunity control [66-68]. 


\section{C Proteins Are Basic and Shuttle between Cytoplasm and Nucleus}

Small proteins $(<25 \mathrm{kDa}$ molecular weight) can traverse the nuclear pore complex by diffusion [69]. Since the molecular weights of $C$ proteins range from 17 to $27 \mathrm{kDa}$, it is not surprising that initial studies reported both the cytoplasmic and nuclear localization of $\mathrm{MeV}$ and $\mathrm{SeV} \mathrm{C}$ proteins [20,70]. In contrast, a report suggested that the NiV C protein is exclusively localized in the cytoplasm [71]. More recent mechanistic analyses revealed that $\mathrm{MeV}, \mathrm{SeV}$ and $\mathrm{NiV} \mathrm{C}$ proteins all shuttle between the cytoplasm and nucleus.

In particular, the MeV C protein sequence ${ }^{75}$ DLEKAMTTLKLWE ${ }^{87}$ includes a nuclear export signal (NES) $[\mathrm{D} / \mathrm{E} / \mathrm{Q}] \mathrm{X}_{0-1}[\mathrm{~L} / \mathrm{I} / \mathrm{M}] \mathrm{X}_{2-3}\left[\mathrm{~L} / \mathrm{I} / \mathrm{V} / \mathrm{M} / \mathrm{F} \mathrm{X}_{2-3}[\mathrm{~L} / \mathrm{M} / \mathrm{V} / \mathrm{F}] \mathrm{X}[\mathrm{L} / \mathrm{M} / \mathrm{I} / \mathrm{V}]\right.$ $\mathrm{X}_{0-3}[\mathrm{D} / \mathrm{E}]$ [72], and $\mathrm{MeV} \mathrm{C}$ may interact with the chromosomal region maintenance $1 \mathrm{nu}-$ clear export protein (CRM1; also known as exportin 1, XPO1). Moreover, a basic amino acid stretch in this protein amino terminal region $\left({ }^{41} \mathrm{PPARKRRQ}{ }^{48}\right)$ serves as the monopartite nuclear localization signal (NLS) for nuclear import by importin- $\alpha / \beta[72,73]$. Thus, NES and NLS sequences allow nucleocytoplasmic shuttling of the MeV C protein [72,73].

For $\mathrm{SeV}$ and NiV C proteins, nonclassical NES and NLS that may act independently of CRM1 or importin- $\alpha / \beta$ have been identified [74,75]. Notably, the location of these sequences within the $C$ proteins of different genera is not conserved, suggesting independent evolution. The independent evolution of nucleocytoplasmic shuttling implies relevance for the viral replication cycle, even if these viruses replicate only in the cytoplasm. By interfering with the nuclear import/export machineries, $C$ proteins may regulate the cellular localization of host factors or the export of host mRNAs from the nucleus [76].

\section{C Proteins Enhance Virulence through Multiple Mechanisms}

In the nucleus or cytoplasm, $\mathrm{C}$ proteins have evolved several different functions. These include the regulation of viral transcription and replication, enhancement of viral polymerase processivity, control of the innate immune response and support of particle assembly and budding (Figure 4). Some of these functions are conserved across the paramyxovirus genera, and others are characteristic of one genus.

The development of reverse genetics technology for mononegaviruses $[77,78]$ was instrumental for the identification and characterization of the different $C$ protein functions. Genetic deletion of the $\mathrm{CORF}$ from the $\mathrm{MeV}$ strain Edmonston $\mathrm{B}$ revealed that this protein is not required for $\mathrm{MeV}$ replication in IFN-defective Vero cells $[9,79,80]$. Similarly, C-deficient respiroviruses, henipaviruses and other morbilliviruses are replication-competent in certain transformed cell lines [81-84] but replicate less efficiently than wild-type viruses in other cell lines or in primary cells [13,65,85-87].

Hence, $C$ proteins are essential antagonists of innate immune responses, a conclusion consistent with the finding that $\mathrm{C}$-deficient viruses generally show a high degree of attenuation in vivo $[13,15,50,65,82,84,88-90]$. For respiroviruses and morbilliviruses, C-deficient mutant viruses exhibit strongly reduced pathogenesis in their natural hosts or animal models $[15,65,82]$. A C protein-deficient $\mathrm{NiV}$ was attenuated in vitro and showed reduced pathogenesis in two different animal models: hamsters and ferrets [91,92]. However, in both cases, the virus could still cause a fatal disease, and in the ferrets, the disease progression was only marginally altered compared to wild-type NiV infection [92]. Taken together, these findings indicate that paramyxoviral $\mathrm{C}$ proteins are virulence factors. However, how do they work? 


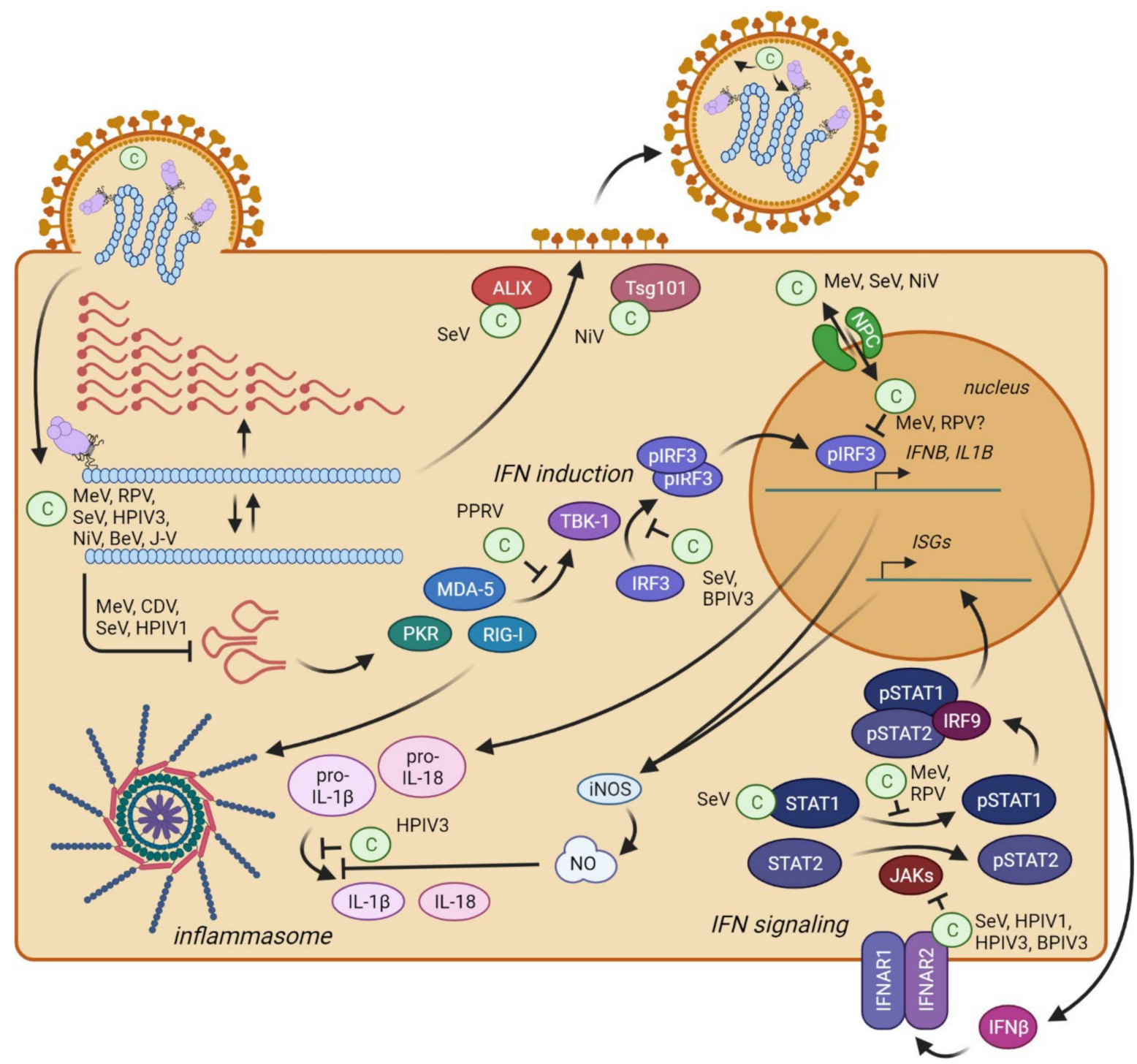

Figure 4. Overview of the localization and functions of the $\mathrm{C}$ protein in the paramyxovirus life cycle, and antagonism of the innate immunity pathways involved in paramyxovirus sensing. (Top left) After cell entry, the viral polymerase transcribes mRNAs and replicates the viral genome. $C$ proteins regulate these processes and prevent the formation of immunostimulatory DI genomes (panhandle structures). (Center) Type-I IFN (IFN $\beta$ ) induction after the sensing of DI genomes by cellular receptors PKR, RIG-I and MDA-5. C proteins can interfere with these processes by blocking the signal transduction cascade at multiple steps in the cytoplasm and nucleus. (Bottom right) Type-I IFN signaling activates the JAK/STAT pathways involving STAT1 and STAT2. The SeV C protein binds and sequesters STAT1; the other C proteins inhibit STAT1 phosphorylation. (Bottom left) The HPIV3 C protein also blocks the inflammasome-mediated activation of IL1 $\beta$. (Top center) The C proteins interact with ESCRT components to enhance virus particle assembly and budding. SeV C interacts with ALIX, and NiV C interacts with Tsg101. (Top right) Several C proteins shuttle between the cytoplasm and nucleus utilizing the nuclear pore complex (NPC). Figure generated with BioRender.com.

\section{C Proteins Regulate Viral Transcription and Replication}

Analyses of $\mathrm{SeV}$ transcription suggested that its $\mathrm{C}$ proteins regulate viral RNA synthesis. The addition of $\mathrm{C}$ proteins to a $\mathrm{SeV}$ in vitro transcription system reduces the amount of transcribed viral mRNA [93], but C-deficient or partially C-defective SeV produce more mRNA than wild-type SeV [94]. A C-deficient $\mathrm{SeV}$ exhibits an altered genome-to-antigenome ratio [95], possibly due to promotor selectivity [96]. In particular, 
in wild-type $\mathrm{SeV}$ particles and infected cells, there are about five times more genomes than antigenomes [95], but this ratio changes with $\mathrm{SeV}$ deficient in $C^{\prime}$ and $C$ proteins $[94,95,97]$. Thus, the $C$ protein may control genome or antigenome synthesis, dictating negative genome polarity by promoting the initiation of RNA synthesis from the antigenomic trailer sequence [97].

Another effect of the $C$ protein is to alter the ratios of different viral RNA species in infected cells [98-100]. In particular, a C-deficient MeV exhibits a steeper transcription gradient than its parental virus [101]. C-deficient Nipah, HPIV3, J and Beilong viruses also have different transcription alterations [102-106]. Altered ratios of the viral RNA species can affect the production of progeny viruses either directly by delaying specific replication processes or indirectly due to the enhanced induction of innate immunity. Notably, C-deficient $\mathrm{SeV}, \mathrm{HPIV} 3, \mathrm{MeV}$ and CDV caused enhanced innate immunity activation $[65,101,107-110]$.

\section{C Proteins Minimize Production of Immunostimulatory DI RNA}

Innate immunity can be activated by viral double-stranded RNA (dsRNA) accidentally generated during viral replication. DsRNA can activate the cytoplasmic pattern recognition receptors that include the RNA sensors retinoic acid inducible gene-I (RIG-I), melanoma differentiation associated gene 5 (MDA-5) and the double-stranded (ds) RNA-dependent protein kinase (PKR). These sensors induce the transcriptional upregulation of type-I IFN (Figure 4, IFN induction).

In infections with C-deficient $\mathrm{SeV}, \mathrm{HPIV} 1, \mathrm{MeV}$ and $\mathrm{CDV}$, large amounts of copy-back defective interfering RNAs (DI RNAs) have been detected $[101,107,110]$, and their structures have been characterized $[65,101,111,112]$. DI RNAs arise when the viral polymerase randomly detaches from the template RNA strand during replication. The polymerase, still bound to the newly synthetized RNA fragment, reinitiates synthesis using the nascent RNA strand as the new template $[101,113,114]$. Consequently, the newly generated RNA molecule is a hybrid of (-)- and (+)-strand RNA with complementary $5^{\prime}$ and $3^{\prime}$ ends. These ends can form double-stranded panhandles that efficiently activate dsRNA sensors RIG-I, MDA-5 and PKR (Figure 4), contributing to virus attenuation [65,101,110-112].

\section{C proteins Interact with the Polymerase Complex}

Thus, C proteins minimize the production of DI RNAs, but how? The mechanisms under investigation include different interaction partners or interaction sequences for different viruses (Figure 5). For SeV C, a direct interaction with L was initially proposed. It was observed that the $\mathrm{SeV} C$ protein colocalizes with the RNP and that this association is resistant to treatment with detergents [115]. The direct association of SeV C and L is consistent with the results of pull-down assays [116]. Other studies conducted with the closely related HPIV3 and the morbillivirus RPV are consistent with direct or indirect C-L interactions $[117,118]$. The interaction site of SeV C with $\mathrm{L}$ was mapped to several charged amino acid carboxy-terminal domains [119], and it was found that the C-L and P-L interaction sites do not overlap [120,121]. The precise understanding of how SeV C interacts with the polymerase complex awaits high-resolution structural analyses that are not yet available, but some considerations can be done based on the available high-resolution structure of the polymerase of another negative-strand RNA virus [122]. By binding to L, SeV C may simply stabilize the L-P complex or rearrange the individual L domains in specific configurations, thereby affecting mRNA synthesis and genome/antigenome replication.

In contrast to $\mathrm{SeV} C$, the $\mathrm{MeV} C$ protein interacts initially with the $\mathrm{N}$ and $\mathrm{P}$ proteins $[68,123]$. This suggests other potential action mechanisms (Figure 5). By interacting with $\mathrm{P}$ and $\mathrm{N}$, the $\mathrm{MeV} C$ protein may influence the encapsidation process of the nascent RNA strand. Improper encapsidation may lead to stalling of the viral polymerase and, eventually, the premature termination of RNA synthesis. Alternatively, $\mathrm{MeV} \mathrm{C}$ may directly stabilize the interaction of the polymerase complex with the template RNP and secure the proper movement of the polymerase along the RNP. As shown for $\mathrm{SeV} \mathrm{C}$, absence of the $\mathrm{MeV} \mathrm{C}$ protein may result in 
the premature termination of RNA synthesis. Notably, the alpha-helical carboxy-terminus of the $\mathrm{MeV}$ C protein is essential and sufficient for its interaction with P [68].

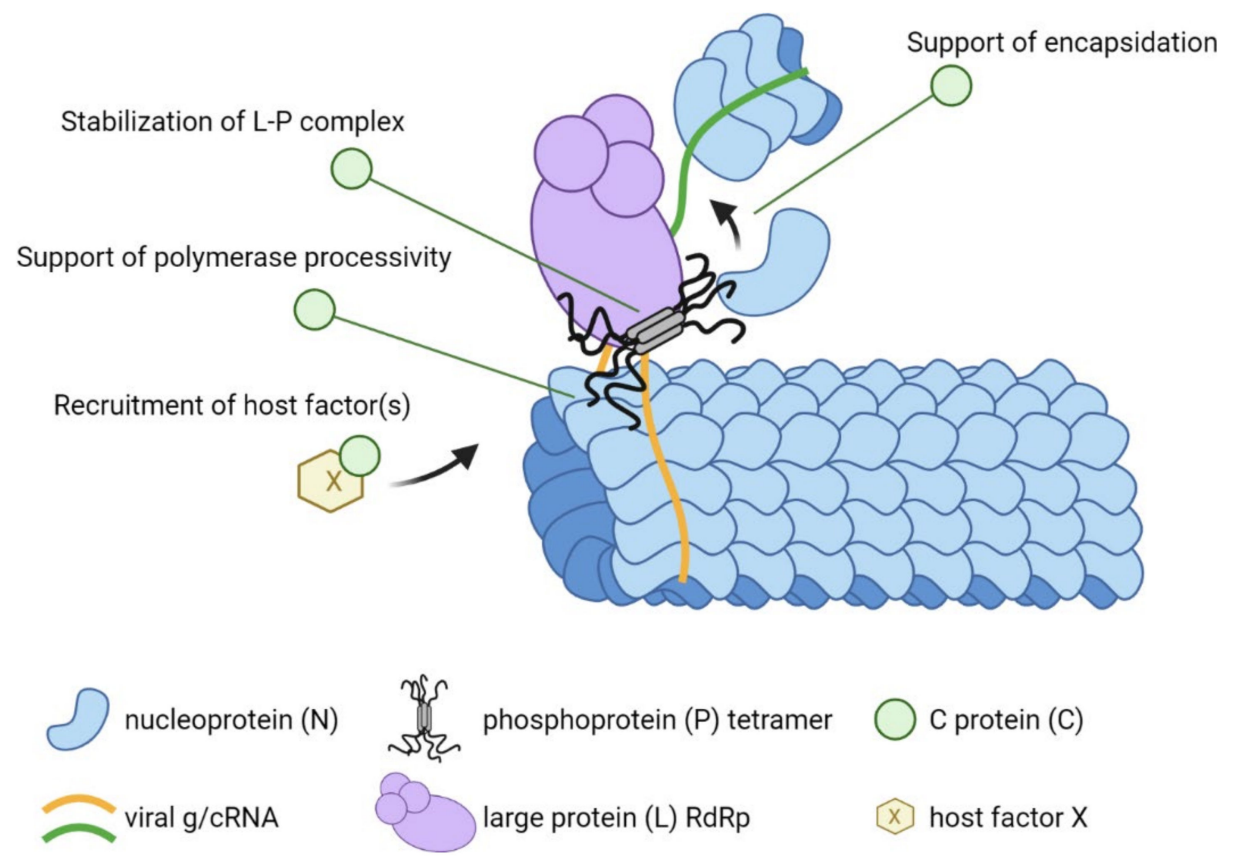

Figure 5. Schematic representation of the replicating paramyxovirus RNP and potential roles of $C$ proteins in enhancing polymerase processivity. The viral nucleocapsid consists of RNA (orange curved line) encapsidated with $\mathrm{N}$ (blue shapes). The viral polymerase consisting of $\mathrm{L}$ (purple) and tetrameric P (grey) extracts viral RNA from the nucleocapsid and synthesizes a complementary sequence (green curved line). P moves the polymerase along the genomic RNA by sequentially interacting with helically arranged $\mathrm{N}$ subunits. $\mathrm{P}$ also interacts with free $\mathrm{N}$ to encapsidate the nascent RNA strand. C proteins may enhance polymerase processivity through one or several of the four indicated mechanisms. Figure generated with BioRender.com.

Interestingly, recent studies have identified several host factors that are recruited to paramyxoviral replication centers to support viral RNA synthesis [124-127]. The MeV C protein specifically recruits host factor SHCBP1 to the viral polymerase complex, which had a positive effect on viral replication [127]. It is likely that $C$ proteins of other paramyxoviruses may also recruit host factors supporting viral replication (Figure 5).

In summary, paramyxoviral $C$ proteins are integral parts of the viral replication complex, controlling polymerase activity and thereby ensuring proper RNA synthesis. Although the $C$ proteins from individual genera may act through different molecular mechanisms, the control of replication is likely a major function that affects the virulence and pathogenesis of all $C$ protein-expressing paramyxoviruses.

\section{C Proteins Directly Interfere with Innate Immunity Activation}

$C$ proteins can directly block the innate immune system at multiple levels (Figure 4). Together with the V proteins [24-28,128], C proteins interfere with IFN induction and signaling and also prevent inflammatory responses. $C$ proteins of different genera share some mechanisms of action, but some $C$ proteins have unique characteristics, probably reflecting viral adaptations to specific hosts or tissues.

\subsection{Interferon Induction}

While the IFN induction pathway (Figure 4, center) is a major target of paramyxoviral $\mathrm{V}$ proteins $[24,128], \mathrm{C}$ proteins also target it. $\mathrm{SeV}$ deficient for all four $\mathrm{C}$ proteins $[\mathrm{SeV}(4 \mathrm{C}-)]$ is a strong inducer of IFN expression $([129,130]$ due to its inability to prevent dsRNA generation [112]. On the other hand, the ectopic expression of $\mathrm{SeV}$ and BPIV3 C proteins 
inhibits phosphorylation and the dimerization of IFN regulatory factor 3 (IRF3) by TANKbinding kinase 1 (TBK-1) induced by foreign stimuli, such as Newcastle disease virus infection, poly(I:C) treatment, 5'-triphosphate containing RNA or infection with SeV DI particles [130-132]. This indicates that the respirovirus $C$ protein may directly interfere with the signal transduction cascade leading to type-I IFN production, but the direct interaction partner has not been identified.

The $\mathrm{C}$ proteins of the morbilliviruses MeV, RPV and PPRV also interfere with IFN induction $[73,133,134]$. However, the phosphorylation, dimerization and nuclear translocation of IRF3 are not affected in cells expressing the MeV or RPV C proteins. On the other hand, the nuclear localization of $\mathrm{MeV} \mathrm{C}$ is essential for the efficient inhibition of IFN $\beta$ induction, suggesting the inhibition of processes involved in IFNB gene transcription occurring in the nucleus [73]. Notably, $\mathrm{MeV}$ vaccine strain $\mathrm{C}$ proteins, which have a mutation in the NLS and, therefore, low nuclear accumulation, have a reduced ability to inhibit IFNB transcription [73]. A recent proteomic analysis of $\mathrm{MeV} \mathrm{C}$ protein interaction partners revealed a weak interaction with the p65 subunit of the nuclear factor kappa $B$ (NF-kB) transcription factor [135], which, in addition to IRF3, is part of the IFNB enhanceosome [136]. While the MeV growth was similar in parental and in p65 knockout cells, growth of the $\mathrm{MeV}-\mathrm{C}^{\mathrm{KO}}$ mutant was significantly enhanced, suggesting that the blocking of p65 by MeV C enhances viral replication [135]. Finally, a recent study suggested that the PPRV C protein can block IFNB promoter activation when a constitutively active form of RIG-I, or its downstream adapter mitochondrial antiviral signaling (MAVS), is expressed but not when downstream signaling components are overexpressed [137]. This suggests that the PPRV C protein, in contrast to the MeV and RPV C proteins, may target a step in the beginning of the signal transduction cascade.

\subsection{Interferon Signaling}

Upon the binding of IFN $\alpha$ or IFN $\beta$ to the type-I IFN receptor complex (IFNAR1/2), a signaling cascade involving receptor-associated tyrosine janus kinases JAK1, JAK2 and TYK2 leads to phosphorylation of the transcription factors STAT1 and STAT2 (Figure 4, IFN signaling). These then associate with IRF9 to form the IFN-stimulated gene factor 3 (ISGF3) complex, which drives the expression of several hundred IFN-stimulated genes (ISGs) under control of the IFN-stimulated response element (ISRE). These genes encode proteins with direct antiviral properties, as well as regulators (activators and suppressors) of the IFN response signaling pathways [138].

Like many other viruses, paramyxoviruses target the IFN-signaling cascade and thereby prevent ISG expression in infected cells. Many paramyxoviruses have evolved more than one mechanism that inhibit IFN signaling. Most importantly, V proteins of paramyxoviruses, and, to some extent P proteins, block IFN signaling by targeting STAT1, STAT2, and the janus kinases [25-28,128]. V proteins bind and block STAT1 via different mechanisms. While some $\mathrm{V}$ proteins, such as those of rubulaviruses, target STAT1 for proteasomal degradation [25-28], others, like morbillivirus V proteins, block its nuclear translocation [86,139]. Morbillivirus V proteins, in addition, bind to STAT2, and their zinc-binding carboxy-terminal domain $\left(\mathrm{V}_{\mathrm{CT}}\right)$ mediates this interaction [140]. In addition, SeV C proteins suppress IFN signaling, indicating how crucial efficient blocking of the IFN response is for this virus [141].

The paramyxovirus $\mathrm{C}$ proteins also contribute to silencing the IFN response. SeV C protein binds STAT1 [142,143], preventing both phosphorylation and dephosphorylation of its residue Y701 that is critical for activation [144,145]. Interestingly, different SeV C proteins act through two different mechanisms. Whereas the long proteins $C^{\prime}$ and $C$ induce STAT1 degradation $[143,146,147]$, the shorter Y1 and Y2 proteins efficiently block STAT1 phosphorylation without inducing degradation [66,146-148].

The co-crystal structure of parts of the SeV C protein with STAT1 (PDB 3WWT; Figure 3A) [59] allows to infer the mechanism underlying this inhibition. The C protein carboxy-terminal globular domain binds to the amino terminal STAT1 domain (ND) via 
charged and hydrophilic interactions along nearly parallel alpha-helices. Unphosphorylated STAT1 forms homodimers or heterodimers via ND interactions, and this dimerization and a conformational change between the subunits lead to the exposure of the Y701 phosphorylation site to the IFNAR-JAK complex [149]. The crystal structure suggests that $\mathrm{SeV}$ C locks STAT1 homodimers and STAT1-STAT2 heterodimers in a conformation unfavorable for phosphorylation $[59,150]$.

While this mechanism depends on the interaction of SeV C proteins with STAT1, additional mechanisms independent of this interaction contribute to the blocking of IFN signaling [151]. By binding to the cytoplasmic tail of IFNAR2, the SeV C protein blocks activation of the janus kinases JAK1 and TYK2 [152]. Notably, this additional mechanism to prevent STAT phosphorylation is conserved across respirovirus C proteins $[152,153]$ and may require the amino terminus [154], while STAT1 binding is specific for the SeV C protein and involves the carboxy-terminus [59].

Morbillivirus C proteins, as exemplified by $\mathrm{MeV}$ and RPV, also interfere with IFN signaling by blocking STAT phosphorylation $[155,156]$. However, a direct comparison of the antagonistic activities of $\mathrm{P}, \mathrm{V}$ and $\mathrm{C}$ proteins suggests that $\mathrm{V}$ is the major morbillivirus antagonist of IFN signaling [25-28]. In contrast, the activity of the $C$ protein is much lower and may vary between different virus strains [155-157]. It is also unknown whether morbillivirus $C$ proteins target IFNAR or JAKs similar to respirovirus $C$ proteins to prevent STAT phosphorylation. Direct interactions of morbillivirus C proteins with either STAT1 or STAT2 have not been detected $[156,157]$.

\subsection{Inflammation}

Inflammatory responses are critical for viral clearance but can also lead to severe pathology in the form of a cytokine storm or cytokine release syndrome. These side effects are reported for numerous respiratory pathogens, such as highly pathogenic influenza A viruses and SARS-CoV-2, as well as pathogens causing hemorrhagic fevers, such as the Ebola virus [158-160]. They are mediated by the excessive production and release of chemokines; IFNs and proinflammatory cytokines such as interleukin 6 (IL-6), IL-1 $\beta$ and IL-18. The transcriptional upregulation of IL-1 $\beta$ and IL-18 during RNA virus infections occurs after viral RNA sensing by RIG-I and MDA-5; however, these cytokines are expressed as inactive pro-forms, which require further activation (Figure 4). This activation is mediated by inflammasomes and inflammasome-associated caspases.

For the recognition of RNA viruses, NLR family pyrin domain containing 3 (NLRP3) is the main inflammasome component [161]. The NLRP3 inflammasome can be activated by viral PAMPs but also by other stimuli (or danger-associated molecular patterns), including uric acid crystals and reactive oxygen species [162,163]. Moreover, nitric oxide (NO), which is generated upon viral infection by inducible nitric oxide synthase (iNOS), is an important regulator of the NLRP3 inflammasome [164]. The expression of iNOS is stimulated by various transcription factors, including NF-kB and IFN- $\gamma$-activated STAT1 homodimers, in response to viral infections $[165,166]$.

The NiV C protein suppresses cytokine and chemokine expression in infected endothelial cells [91,167]. Infection with $\mathrm{C}$ protein-deficient $\mathrm{NiV}(\mathrm{NiV} \Delta \mathrm{C})$ led to increased chemokine and cytokine expression, including IL- $1 \beta$, and, consequently, reduced pathogenesis compared to wild-type NiV infection in a hamster model [91]. The transcriptional upregulation of IL- $1 \beta$ by NiV $\Delta \mathrm{C}$ may be a direct consequence of increased RIG-I/MDA-5 activation by this virus. However, evidence for the inflammasome-mediated activation of IL-1 $\beta$ is missing. Notably, NiV is a hemorrhagic fever virus not associated with a cytokine storm [168].

The SeV C protein affects NO generation by limiting the dsRNA levels in infected cells, which otherwise would trigger an IFN response and lead to the upregulation of iNOS $[169,170]$. This may, in turn, affect inflammasome activation and the activation of proinflammatory cytokines. A more direct effect on the NLRP3 inflammasome has been reported for the SeV V protein: V directly interacts with NLRP3 and inhibits its assembly 
into a functional inflammasome [171]. A similar function was reported for the HPIV3 C protein [172]. The HPIV3 C protein binds to NLRP3 and directs it towards proteasomal degradation, thereby disabling inflammasome assembly. Intriguingly, blocking the NLRP3 inflammasome seems so important for respiroviruses that the $C$ protein has taken over this function from the $\mathrm{V}$ protein in $\mathrm{V}$-deficient viruses. In summary, paramyxoviral C proteins can directly bind to, and interfere with, the function of several cellular proteins required for IFN induction, IFN signaling and inflammation. These $C$ protein tasks are carried out in addition to those supporting efficient and accurate viral replication.

\section{C Proteins Support Viral Particle Assembly and Budding}

Another task performed by $\mathrm{C}$ proteins during the paramyxovirus replication cycle is the support of particle assembly and budding. It was recognized early that the matrix (M) protein is essential to form and release new functional virus particles [173-176]. On the other hand, the M proteins of viruses from different subfamilies have distinct functional characteristics. Those of Orthoparamyxovirinae and Avulavirinae support the budding of virus-like particles (VLPs) that are generated in the absence of any other viral protein or a viral infection, proving that the M protein drives viral budding [177-180].

In the subfamily Rubulavirinae, however, M protein expression alone does not support the efficient budding of VLPs [181,182]. For this subfamily, the co-expression of other structural proteins $(\mathrm{H}, \mathrm{F}$ and $\mathrm{N})$ is required to achieve particle formation efficiencies comparable with a viral infection. The fact that co-expression of the glycoproteins $\mathrm{H}$ and $\mathrm{F}$, as well as proteins of the RNP, modulate the budding of viruses of different Paramyxoviridae genera indicates that the M protein is not solely responsible for the budding process [178,181-186].

Notably, for viruses of the genera Respirovirus and Henipavirus, C proteins are involved in viral budding (Figure 4) $[183,187]$. The co-expression of the SeV C protein with other structural proteins enhances the release of particles in a VLP system [183]. Closer examination of the involvement of SeV C in budding identified the host protein ALIX as an interaction partner of the SeV C protein [188]. ALIX connects the ESCRT-1 protein complex with the ESCRT-3 complex [189-191]. These complexes facilitate protein transport through the multivesicular body and endosomal sorting [192,193].

Recently, the crystal structure of the carboxy-terminal domain of the SeV C protein (Y3) in a complex with the BRO1 domain of ALIX (PDB 6KP3) was resolved at $2.2 \AA$ [61]. Within this structure, a LXXW motif in the SeV C protein interacts with ALIX (Figure 3B), and tryptophan is essential for this interaction [61]. However, for efficient $C$ protein-induced budding, an amino-terminal peptide of 23 residues is also required for the membrane anchoring of C $[188,194,195]$. Therefore, only the $C^{\prime}$ and C proteins are efficient inducers of SeV budding, whereas the Y1 and Y2 proteins are not [194]. Notably, the LXXW motif is conserved among respiroviruses (Figure 3C), and the HPIV1 C protein interacts with ALIX as well [196].

These data suggest that respiroviruses utilize the ESCRT pathway for budding. Indeed, interference with this pathway results in a decreased release of Sendai-VLPs [188,197] and reduced HPIV1 titers [196]. On the other hand, redundancies in the functions of viral M and $\mathrm{C}$ proteins, as well as the different ESCRT systems, suggest that respiroviruses rely on multiple parallel mechanisms for efficient particle release [197,198]. Interestingly, C proteins of some morbilliviruses, namely MeV, CDV and PMV, possess a LXXW motif (Figure 3C). However, MeV C protein does not bind ALIX, and the virus particle release is inefficient and seems independent of the ESCRT pathway $[188,199]$, suggesting that the release of morbillivirus particles may follow a different mechanism.

The NiV C protein interacts with ESCRT factor Tsg101 [187]. This interaction depends on two residues: W103 and L104, which are conserved among henipaviruses (Figure 3D). This WL dipeptide is also conserved in some respirovirus C proteins (Figure 3D), but the evidence for an interaction of respirovirus C proteins with Tsg101 is missing.

In conclusion, the budding mechanisms of paramyxoviruses differ between genera. Respiroviruses and henipaviruses use the ESCRT system for efficient particle release, but the 
corresponding $\mathrm{C}$ proteins have different supporting roles. In contrast, particle release from morbillivirus-infected cells is inefficient and independent of the ESCRT system [199]. These viruses rely on the formation of intercellular fusion pores for cell-to-cell spreading [200-202], and it is unclear whether $\mathrm{C}$ proteins participate in these processes.

\section{Concluding Remarks}

The small C proteins expressed by viruses of three genera of the Orthoparamyxovirinae subfamily control a wide range of viral and cellular processes. All of them modulate the viral polymerase activity, thereby assuring proper RNA synthesis and avoiding the generation of aberrant replication products, which would trigger innate immune responses. In addition, some $C$ proteins directly interfere with the function of specific innate immunity proteins. Finally, some C proteins support efficient viral budding.

While $C$ proteins were initially categorized as nonstructural or accessory, we now understand better why they are so important for viral pathogenesis. Since C proteindeficient viruses are highly attenuated, they could serve as novel live-attenuated vaccines. In addition, novel antiviral therapeutics may target some $C$ protein functions, to be used in combination with existing fusion and polymerase inhibitors [203-205]. In consideration of the multiple functions of paramyxovirus $C$ proteins in the control of virus replication and of the host innate immune response, we propose that C should stand for "control".

Author Contributions: Conceptualization, O.S., R.C. and C.K.P.; methodology, O.S., R.C. and C.K.P.; data curation, O.S., R.C. and C.K.P.; writing-original draft preparation, O.S., R.C. and C.K.P.; writing-review and editing, R.C. and C.K.P.; visualization, O.S. and C.K.P.; supervision, R.C. and C.K.P.; project administration, R.C. and C.K.P. and funding acquisition, R.C. and C.K.P. All authors have read and agreed to the published version of the manuscript.

Funding: This work was supported by the German Research Council Collaborative Research Center (CRC) 1021, Project B12 (Project number 197785619/B12 to C.K.P.) and by R01 AI143791 and R21 AI159230 (to R.C.).

Institutional Review Board Statement: Not applicable.

Informed Consent Statement: Not applicable.

Data Availability Statement: Not applicable.

Conflicts of Interest: The authors declare no conflict of interest.

\section{References}

1. Mountcastle, W.E.; Compans, R.W.; Caliguiri, L.A.; Choppin, P.W. Nucleocapsid protein subunits of simian virus 5, Newcastle disease virus, and Sendai virus. J. Virol. 1970, 6, 677-684. [CrossRef] [PubMed]

2. Mountcastle, W.E.; Compans, R.W.; Choppin, P.W. Proteins and glycoproteins of paramyxoviruses: A comparison of simian virus 5, Newcastle disease virus, and Sendai virus. J. Virol. 1971, 7, 47-52. [CrossRef] [PubMed]

3. Content, J.; Duesberg, P.H. Electrophoretic distribution of the proteins and glycoproteins of influenza virus and Sendai virus. J. Virol. 1970, 6, 707-716. [CrossRef] [PubMed]

4. Shimizu, K.; Hosaka, Y.; Shimizu, Y.K. Solubilization of envelopes of HVJ (Sendai virus) with alkali-emasol treatment and reassembly of envelope particles with removal of the detergent. J. Virol. 1972, 9, 842-850. [CrossRef] [PubMed]

5. Stone, H.O.; Kingsbury, D.W.; Darlington, R.W. Sendai virus-induced transcriptase from infected cells: Polypeptides in the transcriptive complex. J. Virol. 1972, 10, 1037-1043. [CrossRef]

6. Lamb, R.A.; Parks, G. Paramyxoviridae. In Fields Virology, 6th ed.; Knipe, D.M., Howley, P.M., Eds.; Lippincott Williams \& Wilkins: Philadelphia, PA, USA, 2013; pp. 957-995.

7. Lamb, R.A.; Mahy, B.W.; Choppin, P.W. The synthesis of sendai virus polypeptides in infected cells. Virology 1976, 69, 116-131. [CrossRef]

8. Cadd, T.; Garcin, D.; Tapparel, C.; Itoh, M.; Homma, M.; Roux, L.; Curran, J.; Kolakofsky, D. The Sendai paramyxovirus accessory $\mathrm{C}$ proteins inhibit viral genome amplification in a promoter-specific fashion. J. Virol. 1996, 70, 5067-5074. [CrossRef] [PubMed]

9. Radecke, F.; Billeter, M.A. The nonstructural C protein is not essential for multiplication of Edmonston B strain measles virus in cultured cells. Virology 1996, 217, 418-421. [CrossRef] [PubMed]

10. Schneider, H.; Kaelin, K.; Billeter, M.A. Recombinant measles viruses defective for RNA editing and V protein synthesis are viable in cultured cells. Virology 1997, 227, 314-322. [CrossRef] [PubMed] 
11. Nagai, Y.; Kato, A. Accessory genes of the paramyxoviridae, a large family of nonsegmented negative-strand RNA viruses, as a focus of active investigation by reverse genetics. Curr. Top. Microbiol. Immunol. 2004, 283, 197-248. [CrossRef] [PubMed]

12. Kato, A.; Kiyotani, K.; Sakai, Y.; Yoshida, T.; Nagai, Y. The paramyxovirus, Sendai virus, V protein encodes a luxury function required for viral pathogenesis. EMBO J. 1997, 16, 578-587. [CrossRef] [PubMed]

13. Takeuchi, K.; Takeda, M.; Miyajima, N.; Ami, Y.; Nagata, N.; Suzaki, Y.; Shahnewaz, J.; Kadota, S.-I.; Nagata, K. Stringent requirement for the $C$ protein of wild-type measles virus for growth both in vitro and in macaques. J. Virol. 2005, 79, 7838-7844. [CrossRef] [PubMed]

14. Von Messling, V.; Svitek, N.; Cattaneo, R. Receptor (SLAM CD150) recognition and the V protein sustain swift lymphocyte-based invasion of mucosal tissue and lymphatic organs by a morbillivirus. J. Virol. 2006, 80, 6084-6092. [CrossRef]

15. Devaux, P.; Hodge, G.; McChesney, M.B.; Cattaneo, R. Attenuation of V- or C-defective measles viruses: Infection control by the inflammatory and interferon responses of rhesus monkeys. J. Virol. 2008, 82, 5359-5367. [CrossRef] [PubMed]

16. Dowling, P.C.; Giorgi, C.; Roux, L.; Dethlefsen, L.A.; Galantowicz, M.E.; Blumberg, B.M.; Kolakofsky, D. Molecular cloning of the 3'-proximal third of Sendai virus genome. Proc. Natl. Acad. Sci. USA 1983, 80, 5213-5216. [CrossRef]

17. Giorgi, C.; Blumberg, B.M.; Kolakofsky, D. Sendai virus contains overlapping genes expressed from a single mRNA. Cell 1983, 35, 829-836. [CrossRef]

18. Thompson, J.D.; Higgins, D.G.; Gibson, T.J. CLUSTAL W: Improving the sensitivity of progressive multiple sequence alignment through sequence weighting, position-specific gap penalties and weight matrix choice. Nucleic Acids Res.Res. 1994, 22, 4673-4680. [CrossRef] [PubMed]

19. Letunic, I.; Bork, P. Interactive Tree Of Life (iTOL) v5: An online tool for phylogenetic tree display and annotation. Nucleic Acids Res. 2021, 49, W293-W296. [CrossRef]

20. Bellini, W.J.; Englund, G.; Rozenblatt, S.; Arnheiter, H.; Richardson, C.D. Measles virus P gene codes for two proteins. J. Virol. 1985, 53, 908-919. [CrossRef] [PubMed]

21. Harcourt, B.H.; Tamin, A.; Ksiazek, T.G.; Rollin, P.E.; Anderson, L.J.; Bellini, W.J.; Rota, P.A. Molecular characterization of Nipah virus, a newly emergent paramyxovirus. Virology 2000, 271, 334-349. [CrossRef] [PubMed]

22. Thomas, S.M.; Lamb, R.A.; Paterson, R.G. Two mRNAs that differ by two nontemplated nucleotides encode the amino coterminal proteins $\mathrm{P}$ and V of the paramyxovirus SV5. Cell 1988, 54, 891-902. [CrossRef]

23. Cattaneo, R.; Kaelin, K.; Baczko, K.; Billeter, M.A. Measles virus editing provides an additional cysteine-rich protein. Cell 1989, 56, 759-764. [CrossRef]

24. Goodbourn, S.; Randall, R.E. The regulation of type I interferon production by paramyxoviruses. J. Interferon Cytokine Res. 2009, 29, 539-547. [CrossRef] [PubMed]

25. Ramachandran, A.; Horvath, C.M. Paramyxovirus disruption of interferon signal transduction: STATus report. J. Interferon Cytokine Res. 2009, 29, 531-537. [CrossRef] [PubMed]

26. Parks, G.D.; Alexander-Miller, M.A. Paramyxovirus activation and inhibition of innate immune responses. J. Mol. Biol. 2013, 425, 4872-4892. [CrossRef] [PubMed]

27. Audsley, M.D.; Moseley, G.W. Paramyxovirus evasion of innate immunity: Diverse strategies for common targets. World J. Virol. 2013, 2, 57-70. [CrossRef] [PubMed]

28. Horvath, C.M. Silencing STATs: Lessons from paramyxovirus interferon evasion. Cytokine Growth Factor Rev. 2004, 15, 117-127. [CrossRef]

29. Winton, J.R.; Batts, W.N.; Powers, R.L.; Purcell, M.K. Complete Genome Sequences of the Index Isolates of Two Genotypes of Pacific Salmon Paramyxovirus. Microbiol. Resour. Announc. 2019, 8, e01521-18. [CrossRef] [PubMed]

30. Falk, K.; Batts, W.N.; Kvellestad, A.; Kurath, G.; Wiik-Nielsen, J.; Winton, J.R. Molecular characterisation of Atlantic salmon paramyxovirus (ASPV): A novel paramyxovirus associated with proliferative gill inflammation. Virus Res. 2008, 133, 218-227. [CrossRef] [PubMed]

31. Marsh, G.A.; de Jong, C.; Barr, J.A.; Tachedjian, M.; Smith, C.; Middleton, D.; Yu, M.; Todd, S.; Foord, A.J.; Haring, V.; et al. Cedar virus: A novel Henipavirus isolated from Australian bats. PLoS Pathog. 2012, 8, e1002836. [CrossRef] [PubMed]

32. Wang, L.F.; Yu, M.; Hansson, E.; Pritchard, L.I.; Shiell, B.; Michalski, W.P.; Eaton, B.T. The exceptionally large genome of Hendra virus: Support for creation of a new genus within the family Paramyxoviridae. J. Virol. 2000, 74, 9972-9979. [CrossRef] [PubMed]

33. Chua, K.B.; Bellini, W.J.; Rota, P.A.; Harcourt, B.H.; Tamin, A.; Lam, S.K.; Ksiazek, T.G.; Rollin, P.E.; Zaki, S.R.; Shieh, W.; et al Nipah virus: A recently emergent deadly paramyxovirus. Science 2000, 288, 1432-1435. [CrossRef]

34. Li, Z.; Yu, M.; Zhang, H.; Magoffin, D.E.; Jack, P.J.M.; Hyatt, A.; Wang, H.-Y.; Wang, L.-F. Beilong virus, a novel paramyxovirus with the largest genome of non-segmented negative-stranded RNA viruses. Virology 2006, 346, 219-228. [CrossRef] [PubMed]

35. Jack, P.J.M.; Boyle, D.B.; Eaton, B.T.; Wang, L.-F. The complete genome sequence of J virus reveals a unique genome structure in the family Paramyxoviridae. J. Virol. 2005, 79, 10690-10700. [CrossRef]

36. Sidhu, M.S.; Husar, W.; Cook, S.D.; Dowling, P.C.; Udem, S.A. Canine distemper terminal and intergenic non-protein coding nucleotide sequences: Completion of the entire CDV genome sequence. Virology 1993, 193, 66-72. [CrossRef] [PubMed]

37. Rima, B.K.; Collin, A.M.J.; Earle, J.A.P. Completion of the sequence of a cetacean morbillivirus and comparative analysis of the complete genome sequences of four morbilliviruses. Virus Genes 2005, 30, 113-119. [CrossRef] [PubMed] 
38. Woo, P.C.Y.; Lau, S.K.P.; Wong, B.H.L.; Fan, R.Y.Y.; Wong, A.Y.P.; Zhang, A.J.X.; Wu, Y.; Choi, G.K.Y.; Li, K.S.M.; Hui, J.; et al. Feline morbillivirus, a previously undescribed paramyxovirus associated with tubulointerstitial nephritis in domestic cats. Proc. Natl. Acad. Sci. USA 2012, 109, 5435-5440. [CrossRef] [PubMed]

39. Takeuchi, K.; Miyajima, N.; Kobune, F.; Tashiro, M. Comparative nucleotide sequence analyses of the entire genomes of B95a cell-isolated and vero cell-isolated measles viruses from the same patient. Virus Genes 2000, 20, 253-257. [CrossRef] [PubMed]

40. De Vries, R.D.; Verburgh, R.J.; van de Bildt, M.W.G.; Osterhaus, A.D.M.E.; de Swart, R.L. Complete Genome Sequence of Phocine Distemper Virus Isolated from a Harbor Seal (Phoca vitulina) during the 1988 North Sea Epidemic. Genome Announc 2013, 1, e00291-13. [CrossRef]

41. Baron, M.D.; Kamata, Y.; Barras, V.; Goatley, L.; Barrett, T. The genome sequence of the virulent Kabete 'O' strain of rinderpest virus: Comparison with the derived vaccine. J. Gen. Virol. 1996, 77 Pt 12, 3041-3046. [CrossRef] [PubMed]

42. Bailey, D.; Banyard, A.; Dash, P.; Ozkul, A.; Barrett, T. Full genome sequence of peste des petits ruminants virus, a member of the Morbillivirus genus. Virus Res. 2005, 110, 119-124. [CrossRef] [PubMed]

43. Miller, P.J.; Boyle, D.B.; Eaton, B.T.; Wang, L.-F. Full-length genome sequence of Mossman virus, a novel paramyxovirus isolated from rodents in Australia. Virology 2003, 317, 330-344. [CrossRef] [PubMed]

44. Alkhovsky, S.; Butenko, A.; Eremyan, A.; Shchetinin, A. Genetic characterization of bank vole virus (BaVV), a new paramyxovirus isolated from kidneys of bank voles in Russia. Arch. Virol. 2018, 163, 755-759. [CrossRef] [PubMed]

45. Lambeth, L.S.; Yu, M.; Anderson, D.E.; Crameri, G.; Eaton, B.T.; Wang, L.-F. Complete genome sequence of Nariva virus, a rodent paramyxovirus. Arch. Virol. 2009, 154, 199-207. [CrossRef]

46. Tidona, C.A.; Kurz, H.W.; Gelderblom, H.R.; Darai, G. Isolation and molecular characterization of a novel cytopathogenic paramyxovirus from tree shrews. Virology 1999, 258, 425-434. [CrossRef]

47. Bailly, J.E.; McAuliffe, J.M.; Skiadopoulos, M.H.; Collins, P.L.; Murphy, B.R. Sequence determination and molecular analysis of two strains of bovine parainfluenza virus type 3 that are attenuated for primates. Virus Genes 2000, 20, 173-182. [CrossRef]

48. Yang, L.; Li, W.; Mao, L.; Hao, F.; Wang, Z.; Zhang, W.; Deng, J.; Jiang, J. Analysis on the complete genome of a novel caprine parainfluenza virus 3. Infect. Genet. Evol. 2016, 38, 29-34. [CrossRef] [PubMed]

49. Newman, J.T.; Surman, S.R.; Riggs, J.M.; Hansen, C.T.; Collins, P.L.; Murphy, B.R.; Skiadopoulos, M.H. Sequence analysis of the Washington/1964 strain of human parainfluenza virus type 1 (HPIV1) and recovery and characterization of wild-type recombinant HPIV1 produced by reverse genetics. Virus Genes 2002, 24, 77-92. [CrossRef] [PubMed]

50. Durbin, A.P.; McAuliffe, J.M.; Collins, P.L.; Murphy, B.R. Mutations in the C, D, and V open reading frames of human parainfluenza virus type 3 attenuate replication in rodents and primates. Virology 1999, 261, 319-330. [CrossRef]

51. Itoh, M.; Isegawa, Y.; Hotta, H.; Homma, M. Isolation of an avirulent mutant of Sendai virus with two amino acid mutations from a highly virulent field strain through adaptation to LLC-MK2 cells. J. Gen. Virol. 1997, 78 Pt 12, 3207-3215. [CrossRef]

52. Lau, S.K.P.; Woo, P.C.Y.; Wu, Y.; Wong, A.Y.P.; Wong, B.H.L.; Lau, C.C.Y.; Fan, R.Y.Y.; Cai, J.-P.; Tsoi, H.-W.; Chan, K.-H.; et al. Identification and characterization of a novel paramyxovirus, porcine parainfluenza virus 1, from deceased pigs. J. Gen. Virol. 2013, 94, 2184-2190. [CrossRef] [PubMed]

53. Forth, L.F.; Konrath, A.; Klose, K.; Schlottau, K.; Hoffmann, K.; Ulrich, R.G.; Höper, D.; Pohlmann, A.; Beer, M. A Novel Squirrel Respirovirus with Putative Zoonotic Potential. Viruses 2018, 10, 373. [CrossRef] [PubMed]

54. Anderson, D.E.; Dubovi, E.J.; Yu, M.; Wang, L.-F.; Renshaw, R.W. Genome characterization of Salem virus reveals its evolutionary intermediate status in the subfamily Paramyxovirinae. Arch. Virol. 2012, 157, 1989-1993. [CrossRef] [PubMed]

55. Lo, M.K.; Søgaard, T.M.; Karlin, D.G. Evolution and structural organization of the C proteins of paramyxovirinae. PLoS ONE 2014, 9, e90003. [CrossRef] [PubMed]

56. Pei, J.; Kim, B.-H.; Grishin, N.V. PROMALS3D: A tool for multiple protein sequence and structure alignments. Nucleic Acids Res. 2008, 36, 2295-2300. [CrossRef] [PubMed]

57. Madeira, F.; Park, Y.m.; Lee, J.; Buso, N.; Gur, T.; Madhusoodanan, N.; Basutkar, P.; Tivey, A.R.N.; Potter, S.C.; Finn, R.D.; et al The EMBL-EBI search and sequence analysis tools APIs in 2019. Nucleic Acids Res. 2019, 47, W636-W641. [CrossRef] [PubMed]

58. Drozdetskiy, A.; Cole, C.; Procter, J.; Barton, G.J. JPred4: A protein secondary structure prediction server. Nucleic Acids Res. 2015, 43, W389-W394. [CrossRef]

59. Oda, K.; Matoba, Y.; Irie, T.; Kawabata, R.; Fukushi, M.; Sugiyama, M.; Sakaguchi, T. Structural Basis of the Inhibition of STAT1 Activity by Sendai Virus C Protein. J. Virol. 2015, 89, 11487-11499. [CrossRef]

60. Longhi, S.; Bloyet, L.-M.; Gianni, S.; Gerlier, D. How order and disorder within paramyxoviral nucleoproteins and phosphoproteins orchestrate the molecular interplay of transcription and replication. Cell Mol. Life Sci. 2017, 74, 3091-3118. [CrossRef] [PubMed]

61. Oda, K.; Matoba, Y.; Sugiyama, M.; Sakaguchi, T. Structural Insight into the Interaction of Sendai Virus C Protein with Alix To Stimulate Viral Budding. J. Virol. 2021, 95, e0081521. [CrossRef] [PubMed]

62. Boeck, R.; Curran, J.; Matsuoka, Y.; Compans, R.; Kolakofsky, D. The parainfluenza virus type $1 \mathrm{P} / \mathrm{C}$ gene uses a very efficient GUG codon to start its C' protein. J. Virol. 1992, 66, 1765-1768. [CrossRef] [PubMed]

63. Curran, J.A.; Richardson, C.; Kolakofsky, D. Ribosomal initiation at alternate AUGs on the Sendai virus P/C mRNA. J. Virol. 1986, 57, 684-687. [CrossRef] [PubMed] 
64. Kato, A.; Ohnishi, Y.; Kohase, M.; Saito, S.; Tashiro, M.; Nagai, Y. Y2, the smallest of the Sendai virus C proteins, is fully capable of both counteracting the antiviral action of interferons and inhibiting viral RNA synthesis. J. Virol. 2001, 75, 3802-3810. [CrossRef] [PubMed]

65. Siering, O.; Sawatsky, B.; Pfaller, C.K. C Protein is Essential for Canine Distemper Virus Virulence and Pathogenicity in Ferrets. J. Virol. 2020, 95, e01840-20. [CrossRef]

66. Kato, A.; Ohnishi, Y.; Hishiyama, M.; Kohase, M.; Saito, S.; Tashiro, M.; Nagai, Y. The amino-terminal half of Sendai virus C protein is not responsible for either counteracting the antiviral action of interferons or down-regulating viral RNA synthesis. $J$. Virol. 2002, 76, 7114-7124. [CrossRef] [PubMed]

67. Mao, H.; Chattopadhyay, S.; Banerjee, A.K. N-terminally truncated C protein, CNDelta25, of human parainfluenza virus type 3 is a potent inhibitor of viral replication. Virology 2009, 394, 143-148. [CrossRef] [PubMed]

68. Pfaller, C.K.; Bloyet, L.-M.; Donohue, R.C.; Huff, A.L.; Bartemes, W.P.; Yousaf, I.; Urzua, E.; Clavière, M.; Zachary, M.; de Masson d'Autume, V.; et al. The C Protein Is Recruited to Measles Virus Ribonucleocapsids by the Phosphoprotein. J. Virol. 2020, 94, e01733-19. [CrossRef]

69. Timney, B.L.; Raveh, B.; Mironska, R.; Trivedi, J.M.; Kim, S.J.; Russel, D.; Wente, S.R.; Sali, A.; Rout, M.P. Simple rules for passive diffusion through the nuclear pore complex. J. Cell Biol. 2016, 215, 57-76. [CrossRef] [PubMed]

70. Portner, A.; Gupta, K.C.; Seyer, J.M.; Beachey, E.H.; Kingsbury, D.W. Localization and characterization of Sendai virus nonstructural $C$ and $C^{\prime}$ proteins by antibodies against synthetic peptides. Virus Res. 1986, 6, 109-121. [CrossRef]

71. Lo, M.K.; Harcourt, B.H.; Mungall, B.A.; Tamin, A.; Peeples, M.E.; Bellini, W.J.; Rota, P.A. Determination of the henipavirus phosphoprotein gene mRNA editing frequencies and detection of the $\mathrm{C}, \mathrm{V}$ and $\mathrm{W}$ proteins of Nipah virus in virus-infected cells. $J$. Gen. Virol. 2009, 90, 398-404. [CrossRef] [PubMed]

72. Nishie, T.; Nagata, K.; Takeuchi, K. The C protein of wild-type measles virus has the ability to shuttle between the nucleus and the cytoplasm. Microbes Infect. 2007, 9, 344-354. [CrossRef] [PubMed]

73. Sparrer, K.M.J.; Pfaller, C.K.; Conzelmann, K.-K. Measles virus C protein interferes with Beta interferon transcription in the nucleus. J. Virol. 2012, 86, 796-805. [CrossRef]

74. Irie, T.; Yoshida, A.; Sakaguchi, T. Clustered basic amino acids of the small sendai virus C protein Y1 are critical to its RAN GTPase-mediated nuclear localization. PLoS ONE 2013, 8, e73740. [CrossRef]

75. Horie, R.; Yoneda, M.; Uchida, S.; Sato, H.; Kai, C. Region of Nipah virus C protein responsible for shuttling between the cytoplasm and nucleus. Virology 2016, 497, 294-304. [CrossRef] [PubMed]

76. Carmody, S.R.; Wente, S.R. mRNA nuclear export at a glance. J. Cell Sci. 2009, 122, 1933-1937. [CrossRef] [PubMed]

77. Schnell, M.J.; Mebatsion, T.; Conzelmann, K.K. Infectious rabies viruses from cloned cDNA. EMBO J. 1994, 13, 4195-4203. [CrossRef]

78. Radecke, F.; Spielhofer, P.; Schneider, H.; Kaelin, K.; Huber, M.; Dötsch, C.; Christiansen, G.; Billeter, M.A. Rescue of measles viruses from cloned DNA. EMBO J. 1995, 14, 5773-5784. [CrossRef]

79. Desmyter, J.; Melnick, J.L.; Rawls, W.E. Defectiveness of interferon production and of rubella virus interference in a line of African green monkey kidney cells (Vero). J. Virol. 1968, 2, 955-961. [CrossRef]

80. Osada, N.; Kohara, A.; Yamaji, T.; Hirayama, N.; Kasai, F.; Sekizuka, T.; Kuroda, M.; Hanada, K. The genome landscape of the african green monkey kidney-derived vero cell line. DNA Res. 2014, 21, 673-683. [CrossRef] [PubMed]

81. Garcin, D.; Itoh, M.; Kolakofsky, D. A point mutation in the Sendai virus accessory C proteins attenuates virulence for mice, but not virus growth in cell culture. Virology 1997, 238, 424-431. [CrossRef] [PubMed]

82. Kurotani, A.; Kiyotani, K.; Kato, A.; Shioda, T.; Sakai, Y.; Mizumoto, K.; Yoshida, T.; Nagai, Y. Sendai virus C proteins are categorically nonessential gene products but silencing their expression severely impairs viral replication and pathogenesis. Genes Cells 1998, 3, 111-124. [CrossRef] [PubMed]

83. Baron, M.D.; Barrett, T. Rinderpest viruses lacking the $\mathrm{C}$ and $\mathrm{V}$ proteins show specific defects in growth and transcription of viral RNAs. J. Virol. 2000, 74, 2603-2611. [CrossRef] [PubMed]

84. Bartlett, E.J.; Cruz, A.-M.; Boonyaratanakornkit, J.; Esker, J.; Castaño, A.; Skiadopoulos, M.H.; Collins, P.L.; Murphy, B.R.; Schmidt, A.C. A novel human parainfluenza virus type 1 (HPIV1) with separated $P$ and $C$ genes is useful for generating $C$ gene mutants for evaluation as live-attenuated virus vaccine candidates. Vaccine 2010, 28, 767-779. [CrossRef]

85. Escoffier, C.; Manié, S.; Vincent, S.; Muller, C.P.; Billeter, M.; Gerlier, D. Nonstructural C protein is required for efficient measles virus replication in human peripheral blood cells. J. Virol. 1999, 73, 1695-1698. [CrossRef] [PubMed]

86. Devaux, P.; Cattaneo, R. Measles virus phosphoprotein gene products: Conformational flexibility of the P/V protein aminoterminal domain and C protein infectivity factor function. J. Virol. 2004, 78, 11632-11640. [CrossRef]

87. Otsuki, N.; Nakatsu, Y.; Kubota, T.; Sekizuka, T.; Seki, F.; Sakai, K.; Kuroda, M.; Yamaguchi, R.; Takeda, M. The V protein of canine distemper virus is required for virus replication in human epithelial cells. PLoS ONE 2013, 8, e82343. [CrossRef]

88. Valsamakis, A.; Schneider, H.; Auwaerter, P.G.; Kaneshima, H.; Billeter, M.A.; Griffin, D.E. Recombinant measles viruses with mutations in the C, V, or F gene have altered growth phenotypes in vivo. J. Virol. 1998, 72, 7754-7761. [CrossRef]

89. Itoh, M.; Hotta, H.; Homma, M. Increased induction of apoptosis by a Sendai virus mutant is associated with attenuation of mouse pathogenicity. J. Virol. 1998, 72, 2927-2934. [CrossRef] [PubMed]

90. Kato, A.; Kiyotani, K.; Kubota, T.; Yoshida, T.; Tashiro, M.; Nagai, Y. Importance of the anti-interferon capacity of Sendai virus C protein for pathogenicity in mice. J. Virol. 2007, 81, 3264-3271. [CrossRef] 
91. Mathieu, C.; Guillaume, V.; Volchkova, V.A.; Pohl, C.; Jacquot, F.; Looi, R.Y.; Wong, K.T.; Legras-Lachuer, C.; Volchkov, V.E.; Lachuer, J.; et al. Nonstructural Nipah virus $C$ protein regulates both the early host proinflammatory response and viral virulence. J. Virol. 2012, 86, 10766-10775. [CrossRef] [PubMed]

92. Satterfield, B.A.; Cross, R.W.; Fenton, K.A.; Borisevich, V.; Agans, K.N.; Deer, D.J.; Graber, J.; Basler, C.F.; Geisbert, T.W.; Mire, C.E. Nipah Virus C and W Proteins Contribute to Respiratory Disease in Ferrets. J. Virol. 2016, 90, 6326-6343. [CrossRef]

93. Curran, J.; Marq, J.B.; Kolakofsky, D. The Sendai virus nonstructural C proteins specifically inhibit viral mRNA synthesis. Virology 1992, 189, 647-656. [CrossRef]

94. Latorre, P.; Cadd, T.; Itoh, M.; Curran, J.; Kolakofsky, D. The various Sendai virus C proteins are not functionally equivalent and exert both positive and negative effects on viral RNA accumulation during the course of infection. J. Virol. 1998, 72, 5984-5993. [CrossRef]

95. Irie, T.; Nagata, N.; Yoshida, T.; Sakaguchi, T. Paramyxovirus Sendai virus C proteins are essential for maintenance of negativesense RNA genome in virus particles. Virology 2008, 374, 495-505. [CrossRef] [PubMed]

96. Tapparel, C.; Hausmann, S.; Pelet, T.; Curran, J.; Kolakofsky, D.; Roux, L. Inhibition of Sendai virus genome replication due to promoter-increased selectivity: A possible role for the accessory C proteins. J. Virol. 1997, 71, 9588-9599. [CrossRef] [PubMed]

97. Irie, T.; Okamoto, I.; Yoshida, A.; Nagai, Y.; Sakaguchi, T. Sendai virus C proteins regulate viral genome and antigenome synthesis to dictate the negative genome polarity. J. Virol. 2014, 88, 690-698. [CrossRef] [PubMed]

98. Reutter, G.L.; Cortese-Grogan, C.; Wilson, J.; Moyer, S.A. Mutations in the measles virus C protein that up regulate viral RNA synthesis. Virology 2001, 285, 100-109. [CrossRef] [PubMed]

99. Bankamp, B.; Fontana, J.M.; Bellini, W.J.; Rota, P.A. Adaptation to cell culture induces functional differences in measles virus proteins. Virol. J. 2008, 5, 129. [CrossRef] [PubMed]

100. Cattaneo, R.; Rebmann, G.; Schmid, A.; Baczko, K.; ter Meulen, V.; Billeter, M.A. Altered transcription of a defective measles virus genome derived from a diseased human brain. EMBO J. 1987, 6, 681-688. [CrossRef]

101. Pfaller, C.K.; Radeke, M.J.; Cattaneo, R.; Samuel, C.E. Measles virus C protein impairs production of defective copyback double-stranded viral RNA and activation of protein kinase R. J. Virol. 2014, 88, 456-468. [CrossRef]

102. Malur, A.G.; Hoffman, M.A.; Banerjee, A.K. The human parainfluenza virus type 3 (HPIV 3) C protein inhibits viral transcription. Virus Res. 2004, 99, 199-204. [CrossRef] [PubMed]

103. Malur, A.G.; Wells, G.; McCoy, A.; Banerjee, A.K. Evidence for phosphorylation of human parainfluenza virus type 3 C protein Mutant C proteins exhibit variable inhibitory activities in vitro. Virus Res. 2009, 144, 180-187. [CrossRef] [PubMed]

104. Wells, G.; Addington-Hall, M.; Malur, A.G. Mutations within the human parainfluenza virus type 3 (HPIV 3) C protein affect viral replication and host interferon induction. Virus Res. 2012, 167, 385-390. [CrossRef] [PubMed]

105. Sleeman, K.; Bankamp, B.; Hummel, K.B.; Lo, M.K.; Bellini, W.J.; Rota, P.A. The C, V and W proteins of Nipah virus inhibit minigenome replication. J. Gen. Virol. 2008, 89, 1300-1308. [CrossRef]

106. Magoffin, D.E.; Mackenzie, J.S.; Wang, L.-F. Genetic analysis of J-virus and Beilong virus using minireplicons. Virology 2007, 364, 103-111. [CrossRef] [PubMed]

107. Takeuchi, K.; Komatsu, T.; Kitagawa, Y.; Sada, K.; Gotoh, B. Sendai virus C protein plays a role in restricting PKR activation by limiting the generation of intracellular double-stranded RNA. J. Virol. 2008, 82, 10102-10110. [CrossRef]

108. Toth, A.M.; Devaux, P.; Cattaneo, R.; Samuel, C.E. Protein kinase PKR mediates the apoptosis induction and growth restriction phenotypes of C protein-deficient measles virus. J. Virol. 2009, 83, 961-968. [CrossRef] [PubMed]

109. McAllister, C.S.; Toth, A.M.; Zhang, P.; Devaux, P.; Cattaneo, R.; Samuel, C.E. Mechanisms of protein kinase PKR-mediated amplification of beta interferon induction by C protein-deficient measles virus. J. Virol. 2010, 84, 380-386. [CrossRef] [PubMed]

110. Boonyaratanakornkit, J.; Bartlett, E.; Schomacker, H.; Surman, S.; Akira, S.; Bae, Y.-S.; Collins, P.; Murphy, B.; Schmidt, A. The C proteins of human parainfluenza virus type 1 limit double-stranded RNA accumulation that would otherwise trigger activation of MDA5 and protein kinase R. J. Virol. 2011, 85, 1495-1506. [CrossRef]

111. Pfaller, C.K.; Mastorakos, G.M.; Matchett, W.E.; Ma, X.; Samuel, C.E.; Cattaneo, R. Measles Virus Defective Interfering RNAs Are Generated Frequently and Early in the Absence of C Protein and Can Be Destabilized by Adenosine Deaminase Acting on RNA-1-Like Hypermutations. J. Virol. 2015, 89, 7735-7747. [CrossRef]

112. Sánchez-Aparicio, M.T.; Garcin, D.; Rice, C.M.; Kolakofsky, D.; García-Sastre, A.; Baum, A. Loss of Sendai virus C protein leads to accumulation of RIG-I immunostimulatory defective interfering RNA. J. Gen. Virol. 2017, 98, 1282-1293. [CrossRef] [PubMed]

113. Perrault, J. Origin and replication of defective interfering particles. Curr. Top. Microbiol. Immunol. 1981, 93, 151-207. [CrossRef] [PubMed]

114. Calain, P.; Curran, J.; Kolakofsky, D.; Roux, L. Molecular cloning of natural paramyxovirus copy-back defective interfering RNAs and their expression from DNA. Virology 1992, 191, 62-71. [CrossRef]

115. Yamada, H.; Hayata, S.; Omata-Yamada, T.; Taira, H.; Mizumoto, K.; Iwasaki, K. Association of the Sendai virus C protein with nucleocapsids. Arch. Virol. 1990, 113, 245-253. [CrossRef] [PubMed]

116. Horikami, S.M.; Hector, R.E.; Smallwood, S.; Moyer, S.A. The Sendai virus C protein binds the L polymerase protein to inhibit viral RNA synthesis. Virology 1997, 235, 261-270. [CrossRef]

117. Smallwood, S.; Moyer, S.A. The L polymerase protein of parainfluenza virus 3 forms an oligomer and can interact with the heterologous Sendai virus L, P and C proteins. Virology 2004, 318, 439-450. [CrossRef] 
118. Sweetman, D.A.; Miskin, J.; Baron, M.D. Rinderpest virus C and V proteins interact with the major (L) component of the viral polymerase. Virology 2001, 281, 193-204. [CrossRef] [PubMed]

119. Grogan, C.C.; Moyer, S.A. Sendai virus wild-type and mutant $C$ proteins show a direct correlation between $L$ polymerase binding and inhibition of viral RNA synthesis. Virology 2001, 288, 96-108. [CrossRef] [PubMed]

120. Cevik, B.; Smallwood, S.; Moyer, S.A. The L-L oligomerization domain resides at the very N-terminus of the sendai virus L RNA polymerase protein. Virology 2003, 313, 525-536. [CrossRef]

121. Holmes, D.E.; Moyer, S.A. The phosphoprotein $(\mathrm{P})$ binding site resides in the $\mathrm{N}$ terminus of the L polymerase subunit of sendai virus. J. Virol. 2002, 76, 3078-3083. [CrossRef]

122. Liang, B.; Li, Z.; Jenni, S.; Rahmeh, A.A.; Morin, B.M.; Grant, T.; Grigorieff, N.; Harrison, S.C.; Whelan, S.P.J. Structure of the L Protein of Vesicular Stomatitis Virus from Electron Cryomicroscopy. Cell 2015, 162, 314-327. [CrossRef] [PubMed]

123. Nishie, T.; Nagata, K. Measles virus $C$ protein facilitates transcription by the control of $N$ protein-viral genomic RNA interaction in early phases of infection. Biochem. Biophys. Res. Commun. 2015, 463, 1262-1266. [CrossRef] [PubMed]

124. Delpeut, S.; Noyce, R.S.; Siu, R.W.C.; Richardson, C.D. Host factors and measles virus replication. Curr. Opin. Virol. 2012, 2, 773-783. [CrossRef] [PubMed]

125. Bloyet, L.-M.; Welsch, J.; Enchery, F.; Mathieu, C.; de Breyne, S.; Horvat, B.; Grigorov, B.; Gerlier, D. HSP90 Chaperoning in Addition to Phosphoprotein Required for Folding but Not for Supporting Enzymatic Activities of Measles and Nipah Virus L Polymerases. J. Virol. 2016, 90, 6642-6656. [CrossRef] [PubMed]

126. Ma, D.; George, C.X.; Nomburg, J.L.; Pfaller, C.K.; Cattaneo, R.; Samuel, C.E. Upon Infection, Cellular WD Repeat-Containing Protein 5 (WDR5) Localizes to Cytoplasmic Inclusion Bodies and Enhances Measles Virus Replication. J. Virol. 2018, 92. [CrossRef] [PubMed]

127. Ito, M.; Iwasaki, M.; Takeda, M.; Nakamura, T.; Yanagi, Y.; Ohno, S. Measles virus nonstructural C protein modulates viral RNA polymerase activity by interacting with host protein SHCBP1. J. Virol. 2013, 87, 9633-9642. [CrossRef]

128. Ayasoufi, K.; Pfaller, C.K. Seek and hide: The manipulating interplay of measles virus with the innate immune system. Curr. Opin. Virol. 2020, 41, 18-30. [CrossRef]

129. Koyama, A.H.; Irie, H.; Kato, A.; Nagai, Y.; Adachi, A. Virus multiplication and induction of apoptosis by Sendai virus: Role of the C proteins. Microbes Infect. 2003, 5, 373-378. [CrossRef]

130. Komatsu, T.; Takeuchi, K.; Yokoo, J.; Gotoh, B. C and V proteins of Sendai virus target signaling pathways leading to IRF-3 activation for the negative regulation of interferon-beta production. Virology 2004, 325, 137-148. [CrossRef] [PubMed]

131. Komatsu, T.; Takeuchi, K.; Gotoh, B. Bovine parainfluenza virus type 3 accessory proteins that suppress beta interferon production. Microbes Infect. 2007, 9, 954-962. [CrossRef] [PubMed]

132. Strähle, L.; Marq, J.-B.; Brini, A.; Hausmann, S.; Kolakofsky, D.; Garcin, D. Activation of the beta interferon promoter by unnatural Sendai virus infection requires RIG-I and is inhibited by viral C proteins. J. Virol. 2007, 81, 12227-12237. [CrossRef] [PubMed]

133. Boxer, E.L.; Nanda, S.K.; Baron, M.D. The rinderpest virus non-structural C protein blocks the induction of type 1 interferon. Virology 2009, 385, 134-142. [CrossRef]

134. Sanz Bernardo, B.; Goodbourn, S.; Baron, M.D. Control of the induction of type I interferon by Peste des petits ruminants virus. PLoS ONE 2017, 12, e0177300. [CrossRef] [PubMed]

135. Meignié, A.; Combredet, C.; Santolini, M.; Kovács, I.A.; Douché, T.; Gianetto, Q.G.; Eun, H.; Matondo, M.; Jacob, Y.; Grailhe, R.; et al. Proteomic Analysis Uncovers Measles Virus Protein C Interaction With p65-iASPP Protein Complex. Mol. Cell. Proteomics 2021, 20, 100049. [CrossRef] [PubMed]

136. Schafer, S.L.; Lin, R.; Moore, P.A.; Hiscott, J.; Pitha, P.M. Regulation of type I interferon gene expression by interferon regulatory factor-3. J. Biol. Chem. 1998, 273, 2714-2720. [CrossRef]

137. Linjie, L.; Xiaoling, S.; Xiaoxia, M.; Xin, C.; Ali, A.; Jialin, B. Peste des petits ruminants virus non-structural C protein inhibits the induction of interferon- $\beta$ by potentially interacting with MAVS and RIG-I. Virus Genes 2021, 57, 60-71. [CrossRef] [PubMed]

138. Schneider, W.M.; Chevillotte, M.D.; Rice, C.M. Interferon-stimulated genes: A complex web of host defenses. Annu. Rev. Immunol. 2014, 32, 513-545. [CrossRef] [PubMed]

139. Palosaari, H.; Parisien, J.-P.; Rodriguez, J.J.; Ulane, C.M.; Horvath, C.M. STAT protein interference and suppression of cytokine signal transduction by measles virus V protein. J. Virol. 2003, 77, 7635-7644. [CrossRef] [PubMed]

140. Ramachandran, A.; Parisien, J.-P.; Horvath, C.M. STAT2 is a primary target for measles virus V protein-mediated alpha/beta interferon signaling inhibition. J. Virol. 2008, 82, 8330-8338. [CrossRef]

141. Gotoh, B.; Takeuchi, K.; Komatsu, T.; Yokoo, J.; Kimura, Y.; Kurotani, A.; Kato, A.; Nagai, Y. Knockout of the Sendai virus C gene eliminates the viral ability to prevent the interferon-alpha/beta-mediated responses. FEBS Lett. 1999, 459, 205-210. [CrossRef]

142. Takeuchi, K.; Komatsu, T.; Yokoo, J.; Kato, A.; Shioda, T.; Nagai, Y.; Gotoh, B. Sendai virus C protein physically associates with Stat1. Genes Cells 2001, 6, 545-557. [CrossRef] [PubMed]

143. Garcin, D.; Marq, J.-B.; Strahle, L.; Le Mercier, P.; Kolakofsky, D. All four Sendai Virus C proteins bind Stat1, but only the larger forms also induce its mono-ubiquitination and degradation. Virology 2002, 295, 256-265. [CrossRef] [PubMed]

144. Komatsu, T.; Takeuchi, K.; Yokoo, J.; Gotoh, B. Sendai virus C protein impairs both phosphorylation and dephosphorylation processes of Stat1. FEBS Lett. 2002, 511, 139-144. [CrossRef]

145. Saito, S.; Ogino, T.; Miyajima, N.; Kato, A.; Kohase, M. Dephosphorylation failure of tyrosine-phosphorylated STAT1 in IFNstimulated Sendai virus C protein-expressing cells. Virology 2002, 293, 205-209. [CrossRef] 
146. Garcin, D.; Curran, J.; Itoh, M.; Kolakofsky, D. Longer and shorter forms of Sendai virus C proteins play different roles in modulating the cellular antiviral response. J. Virol. 2001, 75, 6800-6807. [CrossRef] [PubMed]

147. Garcin, D.; Marq, J.-B.; Iseni, F.; Martin, S.; Kolakofsky, D. A short peptide at the amino terminus of the Sendai virus C protein acts as an independent element that induces STAT1 instability. J. Virol. 2004, 78, 8799-8811. [CrossRef] [PubMed]

148. Gotoh, B.; Komatsu, T.; Takeuchi, K.; Yokoo, J. The C-terminal half-fragment of the Sendai virus C protein prevents the gammaactivated factor from binding to a gamma-activated sequence site. Virology 2003, 316, 29-40. [CrossRef]

149. Mao, X.; Ren, Z.; Parker, G.N.; Sondermann, H.; Pastorello, M.A.; Wang, W.; McMurray, J.S.; Demeler, B.; Darnell, J.E.; Chen, X. Structural bases of unphosphorylated STAT1 association and receptor binding. Mol. Cell 2005, 17, 761-771. [CrossRef] [PubMed]

150. Oda, K.; Oda, T.; Matoba, Y.; Sato, M.; Irie, T.; Sakaguchi, T. Structural analysis of the STAT1:STAT2 heterodimer revealed the mechanism of Sendai virus C protein-mediated blockade of type 1 interferon signaling. J. Biol. Chem. 2017, 292, 19752-19766. [CrossRef]

151. Gotoh, B.; Takeuchi, K.; Komatsu, T. Inhibition of the gamma interferon response by a Sendai virus C protein mutant with no STAT1-binding ability. FEBS Lett. 2004, 567, 291-296. [CrossRef] [PubMed]

152. Kitagawa, Y.; Yamaguchi, M.; Kohno, M.; Sakai, M.; Itoh, M.; Gotoh, B. Respirovirus C protein inhibits activation of type I interferon receptor-associated kinases to block JAK-STAT signaling. FEBS Lett. 2020, 594, 864-877. [CrossRef] [PubMed]

153. Malur, A.G.; Chattopadhyay, S.; Maitra, R.K.; Banerjee, A.K. Inhibition of STAT 1 phosphorylation by human parainfluenza virus type 3 C protein. J. Virol. 2005, 79, 7877-7882. [CrossRef] [PubMed]

154. Mao, H.; Chattopadhyay, S.; Banerjee, A.K. Domain within the C protein of human parainfluenza virus type 3 that regulates interferon signaling. Gene Expr. 2010, 15, 43-50. [CrossRef] [PubMed]

155. Shaffer, J.A.; Bellini, W.J.; Rota, P.A. The C protein of measles virus inhibits the type I interferon response. Virology 2003, 315, 389-397. [CrossRef]

156. Nanda, S.K.; Baron, M.D. Rinderpest virus blocks type I and type II interferon action: Role of structural and nonstructural proteins. J. Virol. 2006, 80, 7555-7568. [CrossRef]

157. Takeuchi, K.; Kadota, S.; Takeda, M.; Miyajima, N.; Nagata, K. Measles virus V protein blocks interferon (IFN)-alpha/beta but not IFN-gamma signaling by inhibiting STAT1 and STAT2 phosphorylation. FEBS Lett. 2003, 545, 177-182. [CrossRef]

158. Tisoncik, J.R.; Korth, M.J.; Simmons, C.P.; Farrar, J.; Martin, T.R.; Katze, M.G. Into the eye of the cytokine storm. Microbiol. Mol. Biol. Rev. 2012, 76, 16-32. [CrossRef]

159. Paessler, S.; Walker, D.H. Pathogenesis of the viral hemorrhagic fevers. Annu. Rev. Pathol. 2013, 8, 411-440. [CrossRef]

160. Vora, S.M.; Lieberman, J.; Wu, H. Inflammasome activation at the crux of severe COVID-19. Nat. Rev. Immunol. 2021, 21, 694-703. [CrossRef] [PubMed]

161. Spel, L.; Martinon, F. Detection of viruses by inflammasomes. Curr. Opin. Virol. 2021, 46, 59-64. [CrossRef] [PubMed]

162. Ogura, Y.; Sutterwala, F.S.; Flavell, R.A. The inflammasome: First line of the immune response to cell stress. Cell 2006, 126, 659-662. [CrossRef] [PubMed]

163. Tschopp, J.; Schroder, K. NLRP3 inflammasome activation: The convergence of multiple signalling pathways on ROS production? Nat. Rev. Immunol. 2010, 10, 210-215. [CrossRef]

164. Mishra, B.B.; Rathinam, V.A.K.; Martens, G.W.; Martinot, A.J.; Kornfeld, H.; Fitzgerald, K.A.; Sassetti, C.M. Nitric oxide controls the immunopathology of tuberculosis by inhibiting NLRP3 inflammasome-dependent processing of IL-1 $\beta$. Nat. Immunol. 2013, 14, 52-60. [CrossRef] [PubMed]

165. Akaike, T.; Maeda, H. Nitric oxide and virus infection. Immunology 2000, 101, 300-308. [CrossRef]

166. Uehara, E.U.; Shida, B.d.S.; de Brito, C.A. Role of nitric oxide in immune responses against viruses: Beyond microbicidal activity. Inflamm. Res. 2015, 64, 845-852. [CrossRef] [PubMed]

167. Lo, M.K.; Peeples, M.E.; Bellini, W.J.; Nichol, S.T.; Rota, P.A.; Spiropoulou, C.F. Distinct and overlapping roles of Nipah virus P gene products in modulating the human endothelial cell antiviral response. PLoS ONE 2012, 7, e47790. [CrossRef]

168. Lara, A.; Cong, Y.; Jahrling, P.B.; Mednikov, M.; Postnikova, E.; Yu, S.; Munster, V.; Holbrook, M.R. Peripheral immune response in the African green monkey model following Nipah-Malaysia virus exposure by intermediate-size particle aerosol. PLoS Negl. Trop. Dis. 2019, 13, e0007454. [CrossRef]

169. Odkhuu, E.; Komatsu, T.; Naiki, Y.; Koide, N.; Yokochi, T. Sendai virus C protein inhibits lipopolysaccharide-induced nitric oxide production through impairing interferon- $\beta$ signaling. Int. Immunopharmacol. 2014, 23, 267-272. [CrossRef]

170. Odkhuu, E.; Komatsu, T.; Koide, N.; Naiki, Y.; Takeuchi, K.; Tanaka, Y.; Tsolmongyn, B.; Jambalganiin, U.; Morita, N.; Yoshida, T.; et al. Sendai virus C protein limits NO production in infected RAW264.7 macrophages. Innate Immun. 2018, 24, 430-438. [CrossRef] [PubMed]

171. Komatsu, T.; Tanaka, Y.; Kitagawa, Y.; Koide, N.; Naiki, Y.; Morita, N.; Gotoh, B.; Yokochi, T. Sendai Virus V Protein Inhibits the Secretion of Interleukin-1 $\beta$ by Preventing NLRP3 Inflammasome Assembly. J. Virol. 2018, 92, e00842-18. [CrossRef] [PubMed]

172. Shil, N.K.; Pokharel, S.M.; Banerjee, A.K.; Hoffman, M.; Bose, S. Inflammasome Antagonism by Human Parainfluenza Virus Type 3 C Protein. J. Virol. 2018, 92. [CrossRef] [PubMed]

173. Peeples, M.E. Paramyxovirus M Proteins. In The Paramyxoviruses; Kingsbury, D.W., Ed.; Springer: Boston, MA, USA, 1991; pp. 427-456, ISBN 978-0-306-43553-9. 
174. Cathomen, T.; Mrkic, B.; Spehner, D.; Drillien, R.; Naef, R.; Pavlovic, J.; Aguzzi, A.; Billeter, M.A.; Cattaneo, R. A matrixless measles virus is infectious and elicits extensive cell fusion: Consequences for propagation in the brain. $E M B O J$. 1998, 17, 3899-3908. [CrossRef] [PubMed]

175. Takimoto, T.; Portner, A. Molecular mechanism of paramyxovirus budding. Virus Res. 2004, 106, 133-145. [CrossRef] [PubMed]

176. Cox, R.M.; Plemper, R.K. Structure and organization of paramyxovirus particles. Curr. Opin. Virol. 2017, 24, 105-114. [CrossRef] [PubMed]

177. Coronel, E.C.; Murti, K.G.; Takimoto, T.; Portner, A. Human parainfluenza virus type 1 matrix and nucleoprotein genes transiently expressed in mammalian cells induce the release of virus-like particles containing nucleocapsid-like structures. J. Virol. 1999, 73, 7035-7038. [CrossRef] [PubMed]

178. Takimoto, T.; Murti, K.G.; Bousse, T.; Scroggs, R.A.; Portner, A. Role of matrix and fusion proteins in budding of Sendai virus. J. Virol. 2001, 75, 11384-11391. [CrossRef]

179. Ciancanelli, M.J.; Basler, C.F. Mutation of YMYL in the Nipah virus matrix protein abrogates budding and alters subcellular localization. J. Virol. 2006, 80, 12070-12078. [CrossRef] [PubMed]

180. Pohl, C.; Duprex, W.P.; Krohne, G.; Rima, B.K.; Schneider-Schaulies, S. Measles virus M and F proteins associate with detergentresistant membrane fractions and promote formation of virus-like particles. J. Gen. Virol. 2007, 88, 1243-1250. [CrossRef] [PubMed]

181. Schmitt, A.P.; Leser, G.P.; Waning, D.L.; Lamb, R.A. Requirements for budding of paramyxovirus simian virus 5 virus-like particles. J. Virol. 2002, 76, 3952-3964. [CrossRef]

182. Li, M.; Schmitt, P.T.; Li, Z.; McCrory, T.S.; He, B.; Schmitt, A.P. Mumps virus matrix, fusion, and nucleocapsid proteins cooperate for efficient production of virus-like particles. J. Virol. 2009, 83, 7261-7272. [CrossRef] [PubMed]

183. Sugahara, F.; Uchiyama, T.; Watanabe, H.; Shimazu, Y.; Kuwayama, M.; Fujii, Y.; Kiyotani, K.; Adachi, A.; Kohno, N.; Yoshida, T.; et al. Paramyxovirus Sendai virus-like particle formation by expression of multiple viral proteins and acceleration of its release by C protein. Virology 2004, 325, 1-10. [CrossRef] [PubMed]

184. Patch, J.R.; Crameri, G.; Wang, L.-F.; Eaton, B.T.; Broder, C.C. Quantitative analysis of Nipah virus proteins released as virus-like particles reveals central role for the matrix protein. Virol. J. 2007, 4, 1. [CrossRef]

185. Johnston, G.P.; Contreras, E.M.; Dabundo, J.; Henderson, B.A.; Matz, K.M.; Ortega, V.; Ramirez, A.; Park, A.; Aguilar, H.C. Cytoplasmic Motifs in the Nipah Virus Fusion Protein Modulate Virus Particle Assembly and Egress. J. Virol. 2017, 91, e02150-16. [CrossRef] [PubMed]

186. Pantua, H.D.; McGinnes, L.W.; Peeples, M.E.; Morrison, T.G. Requirements for the assembly and release of Newcastle disease virus-like particles. J. Virol. 2006, 80, 11062-11073. [CrossRef] [PubMed]

187. Park, A.; Yun, T.; Vigant, F.; Pernet, O.; Won, S.T.; Dawes, B.E.; Bartkowski, W.; Freiberg, A.N.; Lee, B. Nipah Virus C Protein Recruits Tsg101 to Promote the Efficient Release of Virus in an ESCRT-Dependent Pathway. PLoS Pathog. 2016, 12, e1005659. [CrossRef]

188. Sakaguchi, T.; Kato, A.; Sugahara, F.; Shimazu, Y.; Inoue, M.; Kiyotani, K.; Nagai, Y.; Yoshida, T. AIP1/Alix is a binding partner of Sendai virus C protein and facilitates virus budding. J. Virol. 2005, 79, 8933-8941. [CrossRef] [PubMed]

189. Martin-Serrano, J.; Yarovoy, A.; Perez-Caballero, D.; Bieniasz, P.D.; Yaravoy, A. Divergent retroviral late-budding domains recruit vacuolar protein sorting factors by using alternative adaptor proteins. Proc. Natl. Acad. Sci. USA 2003, 100, 12414-12419. [CrossRef] [PubMed]

190. Katoh, K.; Shibata, H.; Suzuki, H.; Nara, A.; Ishidoh, K.; Kominami, E.; Yoshimori, T.; Maki, M. The ALG-2-interacting protein Alix associates with CHMP4b, a human homologue of yeast Snf7 that is involved in multivesicular body sorting. J. Biol. Chem. 2003, 278, 39104-39113. [CrossRef]

191. Peck, J.W.; Bowden, E.T.; Burbelo, P.D. Structure and function of human Vps20 and Snf7 proteins. Biochem. J. 2004, 377, 693-700. [CrossRef] [PubMed]

192. Katzmann, D.J.; Babst, M.; Emr, S.D. Ubiquitin-dependent sorting into the multivesicular body pathway requires the function of a conserved endosomal protein sorting complex, ESCRT-I. Cell 2001, 106, 145-155. [CrossRef]

193. Babst, M.; Katzmann, D.J.; Estepa-Sabal, E.J.; Meerloo, T.; Emr, S.D. Escrt-III: An endosome-associated heterooligomeric protein complex required for mvb sorting. Dev. Cell 2002, 3, 271-282. [CrossRef]

194. Irie, T.; Nagata, N.; Yoshida, T.; Sakaguchi, T. Recruitment of Alix/AIP1 to the plasma membrane by Sendai virus C protein facilitates budding of virus-like particles. Virology 2008, 371, 108-120. [CrossRef]

195. Marq, J.-B.; Brini, A.; Kolakofsky, D.; Garcin, D. Targeting of the Sendai virus C protein to the plasma membrane via a peptide-only membrane anchor. J. Virol. 2007, 81, 3187-3197. [CrossRef] [PubMed]

196. Boonyaratanakornkit, J.; Schomacker, H.; Collins, P.; Schmidt, A. Alix serves as an adaptor that allows human parainfluenza virus type 1 to interact with the host cell ESCRT system. PLoS ONE 2013, 8, e59462. [CrossRef]

197. Irie, T.; Shimazu, Y.; Yoshida, T.; Sakaguchi, T. The YLDL sequence within Sendai virus M protein is critical for budding of virus-like particles and interacts with Alix/AIP1 independently of C protein. J. Virol. 2007, 81, 2263-2273. [CrossRef] [PubMed]

198. Gosselin-Grenet, A.-S.; Marq, J.-B.; Abrami, L.; Garcin, D.; Roux, L. Sendai virus budding in the course of an infection does not require Alix and VPS4A host factors. Virology 2007, 365, 101-112. [CrossRef] [PubMed] 
199. Salditt, A.; Koethe, S.; Pohl, C.; Harms, H.; Kolesnikova, L.; Becker, S.; Schneider-Schaulies, S. Measles virus M protein-driven particle production does not involve the endosomal sorting complex required for transport (ESCRT) system. J. Gen. Virol. 2010, 91, 1464-1472. [CrossRef] [PubMed]

200. Singh, B.K.; Hornick, A.L.; Krishnamurthy, S.; Locke, A.C.; Mendoza, C.A.; Mateo, M.; Miller-Hunt, C.L.; Cattaneo, R.; Sinn, P.L. The Nectin-4/Afadin Protein Complex and Intercellular Membrane Pores Contribute to Rapid Spread of Measles Virus in Primary Human Airway Epithelia. J. Virol. 2015, 89, 7089-7096. [CrossRef] [PubMed]

201. Singh, B.K.; Pfaller, C.K.; Cattaneo, R.; Sinn, P.L. Measles Virus Ribonucleoprotein Complexes Rapidly Spread across WellDifferentiated Primary Human Airway Epithelial Cells along F-Actin Rings. mBio 2019, 10. [CrossRef]

202. Cifuentes-Muñoz, N.; Dutch, R.E.; Cattaneo, R. Direct cell-to-cell transmission of respiratory viruses: The fast lanes. PLoS Pathog. 2018, 14, e1007015. [CrossRef] [PubMed]

203. Contreras, E.M.; Monreal, I.A.; Ruvalcaba, M.; Ortega, V.; Aguilar, H.C. Antivirals targeting paramyxovirus membrane fusion. Curr. Opin. Virol. 2021, 51, 34-47. [CrossRef] [PubMed]

204. Cox, R.M.; Sourimant, J.; Toots, M.; Yoon, J.-J.; Ikegame, S.; Govindarajan, M.; Watkinson, R.E.; Thibault, P.; Makhsous, N.; Lin, M.J.; et al. Orally efficacious broad-spectrum allosteric inhibitor of paramyxovirus polymerase. Nat. Microbiol. 2020, 5, $1232-1246$. [CrossRef] [PubMed]

205. Plemper, R.K. Measles Resurgence and Drug Development. Curr. Opin. Virol. 2020, 41, 8-17. [CrossRef] [PubMed] 